\title{
Business Ownership and Sectoral Growth
}

Citation for published version (APA):

Carree, M. A., \& van Stel , A. (2004). Business Ownership and Sectoral Growth. International Small Business Journal, 22, 389-419. https://doi.org/10.1177/0266242604044306

Document status and date:

Published: 01/01/2004

DOI:

10.1177/0266242604044306

Document Version:

Publisher's PDF, also known as Version of record

\section{Please check the document version of this publication:}

- A submitted manuscript is the version of the article upon submission and before peer-review. There can be important differences between the submitted version and the official published version of record.

People interested in the research are advised to contact the author for the final version of the publication, or visit the DOI to the publisher's website.

- The final author version and the galley proof are versions of the publication after peer review.

- The final published version features the final layout of the paper including the volume, issue and page numbers.

Link to publication

\footnotetext{
General rights rights.

- You may freely distribute the URL identifying the publication in the public portal. please follow below link for the End User Agreement:

www.umlib.nl/taverne-license

Take down policy

If you believe that this document breaches copyright please contact us at:

repository@maastrichtuniversity.nl

providing details and we will investigate your claim.
}

Copyright and moral rights for the publications made accessible in the public portal are retained by the authors and/or other copyright owners and it is a condition of accessing publications that users recognise and abide by the legal requirements associated with these

- Users may download and print one copy of any publication from the public portal for the purpose of private study or research.

- You may not further distribute the material or use it for any profit-making activity or commercial gain

If the publication is distributed under the terms of Article $25 \mathrm{fa}$ of the Dutch Copyright Act, indicated by the "Taverne" license above, 
International Small Business Journal

Copyright (C) 2004

SAGE Publications (London,

Thousand Oaks and New Delhi)

[DOl: 10.1 177/0266242604044306]

Vol 22(4): $389-419$

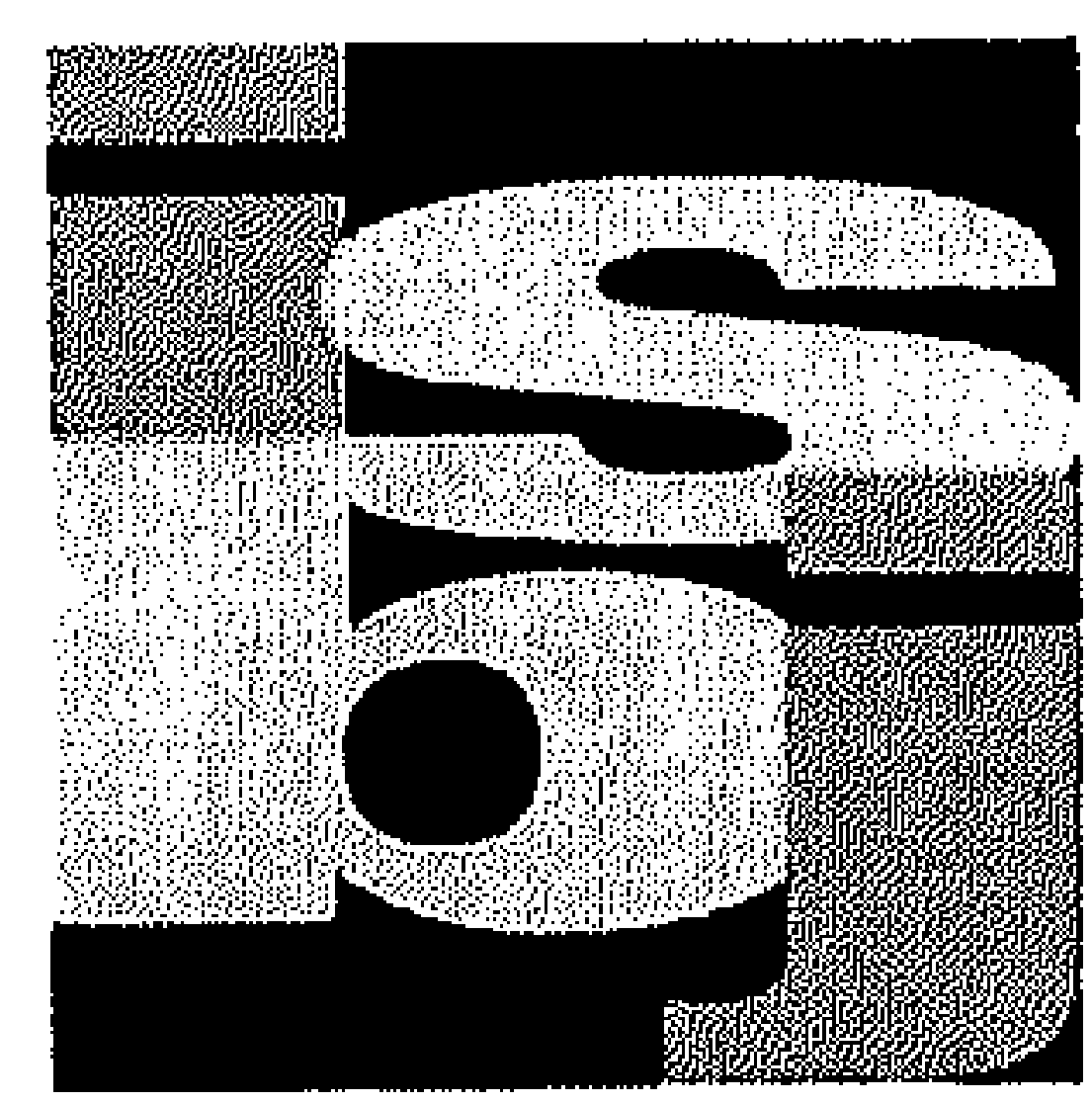

\title{
Business Ownership and Sectoral Growth
}

\author{
An Empirical Analysis of 21 OECD Countries
}

\author{
ANDRÉ VAN STEL \\ EIM Business and Policy Research, The Netherlands
}

\author{
MARTIN CARREE \\ University of Maastricht, The Netherlands
}

We investigate the development of business ownership (self-employment) rates over time at the sectoral level and the effect of these rates on sectoral output growth. In an earlier exercise, Carree et al. (2002) presented an analysis of the interrelationship between economy-wide business ownership rates and economic development. Their analysis raised an important research question: to what extent do differences in business ownership rates at the economy-wide level reflect differences in the sectoral structures of economies or differences in business ownership rates at the sectoral level? The current article investigates this question making use of a sectoral data base of 21 OECD countries for the period 1970-98. Estimation results suggest that there is, on average, a too low business ownership rate in manufacturing and a too high business ownership rate in services.

KEYWORDS: business ownership; economic growth; entrepreneurship; manufacturing; services

\section{Introduction}

The empirical growth literature has generated a long list of regressors assumed to affect economic growth. The regressors range from schooling to climate and from the extent of democracy to life expectancy (see for example Bleaney and Nishiyama, 2002). These factors are of considerable importance and it is for example unlikely that a non-democratic country with an extreme climate will be found to show fast economic growth, except when oil or other natural resources come into play. However, little attention in the empirical growth literature has been devoted to entrepreneurship and competition, usually considered vital to economic progress. The lack of economic progress in (formerly) centralized planned economies has been at least partly due to the absence of these private 


\section{International Small Business Journal 22(4)}

initiatives. A characteristic of these economies was the almost complete absence of small firms and this extreme monopolization was a major factor leading to the collapse of state socialism (see for example Acs, 1996; Ellman, 1993). The incorporation of entrepreneurship and competition into empirical growth models has been hampered by the problem of measurement. However, a small literature has developed that investigates the effect of the industry structure, in terms of the share of small firms, on economic progress. Examples include Nickell (1996), Carree and Thurik (1998), Audretsch et al. (2002) and Carree (2002a).

Recently, Carree et al. (2002) introduced a model that describes the interrelationship between the rate of business ownership (or, interchangeably, selfemployment) and economic development. This model consists of two equations, which are estimated successively. In the first equation, an 'equilibrium' relation is derived between the rate of business ownership and the level of economic development of a country. In the second equation the impact on economic growth of deviating from the 'equilibrium' rate is estimated. The basic idea behind the model is that there can be too many or too few self-employed in an economy. A consequence of a too high business ownership rate in a country is that economies of scale and scope are not benefited from and that R\&D expenditures may be relatively low. A consequence of a too low business ownership rate is that new private initiatives and radical new innovations may be less present than in other countries at comparable levels of economic development. Carree et al. present empirical evidence for the 'equilibrium' rate of business ownership to depend upon the stage of economic development and that deviating from the 'equilibrium' implies a lower economic growth rate.

The article by Carree et al. suffers from an important limitation. It studies the relationship between business ownership rates at the economy-wide level without taking into consideration the sectoral structure of the economy. It is well known that business ownership rates are much higher in the service sector when compared to the manufacturing sector. It is therefore possible that the penalty of deviating from the 'equilibrium' business ownership rate is not a problem of having too few or too many self-employed, but a problem of having a too small or a too large share of the service sector. Carree et al. find that the 'equilibrium' business ownership rates tend to increase with the level of economic development for the highly most developed countries (in terms of GDP per capita). This might be caused by increased interest for the option of self-employment as such across the sectors in the economy, but may also be explained from an employment shift in modern economies away from the manufacturing sector towards the service sector. The current article examines the importance of the sectoral component in the Carree et al. model, using data for 21 OECD countries. The 21 countries include 16 European countries, the USA, Canada, Japan, Australia and New Zealand.

There is a lot of debate about the reasons behind the increase in selfemployment rates in developed countries in the last quarter of the 20th century. On the one hand, Audretsch and Thurik (2000) consider it to be a reflection of the shift from a 'managed' towards an 'entrepreneurial' economy. They claim 
Van Stel and Carree: Business Ownership and Sectoral Growth

that there is more room for business ownership in the latter type of economy because of, among others, increasing variety of demand and rapidly changing economic circumstances in which small firms have a comparative advantage with regard to their larger counterparts. These phenomena particularly apply to fully industrialized economies and therefore, this upward trend of business ownership would only be observable in countries at higher stages of economic development. On the other hand, other economists will say that this upward trend of the macro business ownership rate in modern economies is just a reflection of the (employment) share of the service industries increasing at the cost of the manufacturing industries' share. According to these economists it does not imply that also within sectors there would be an upward trend in business ownership. The current analysis gathers business ownership data on the sectoral level and applies the model of Carree et al. at this level. In this way, we can determine whether or not the structural changes in business ownership do also apply within sectors. In particular, we will estimate the model for two sectors: manufacturing and services.

In section 2 we will discuss the Carree et al. model and adapt it to make it applicable at the sectoral level. We also discuss the relevant literature. In section 3 we discuss the data for the OECD countries. This is followed by the empirical results in section 4. Section 5 is left for discussion.

\section{Theory and model}

Carree et al. $(2000,2002)$ introduced a model consisting of two equations with one additional equation defining the 'equilibrium' rate of business ownership in period $t, E_{t}^{*}$. The dependent variables of the two equations are the four-year change in the business ownership rate, $E_{t}-E_{t-4}$, and the four-year growth rate of GDP, $\left(Y_{t}-Y_{t-4}\right) / Y_{t-4}$. We use the same model configuration in our analysis but adapt it somewhat to apply it to the sectoral level. The model reads as follows.

$$
\begin{aligned}
& E_{i j t}-E_{i j, t-4}=b_{1}\left(E_{i j, t-4}^{*}-E_{i j, t-4}\right)+b_{2}\left(U_{i, t-4}-\bar{U}\right)+b_{3} Y_{-} \text {share }_{i j, t-4}+b_{I T A} D_{I T A}+\varepsilon_{1 j i t} \\
& \frac{\Delta_{4} Y_{i j t}}{Y_{i j, t-4}}=c_{0}+c_{1}\left|E_{i j, t-4}^{*}-E_{i j, t-4}\right|+c_{2} Y C A P_{i, t-4}+c_{3} Y_{-} \text {share }_{i j, t-4}+ \\
& c_{4} W T_{t}+c_{5} W T_{t-2}+c_{6} W T_{t-4}+\varepsilon_{2 i j t} \\
& E_{i, t,}^{*}=f\left(Y C A P_{i t}\right) \times\left(1+b_{O M I B} D_{O M I B}\right)
\end{aligned}
$$

The symbols in these equations stand for the following variables:

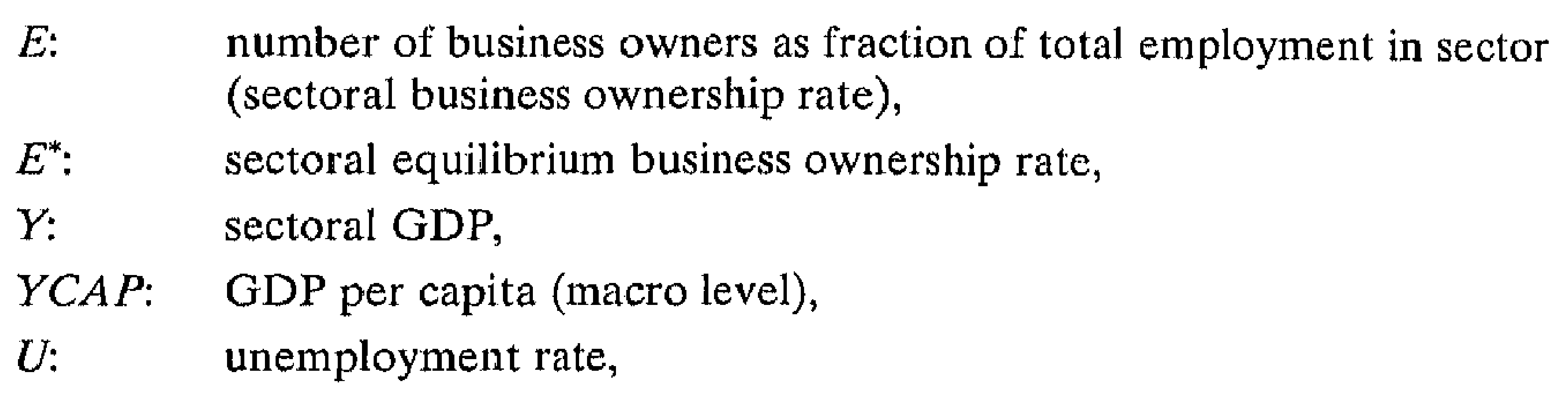


International Small Business Journal 22(4)

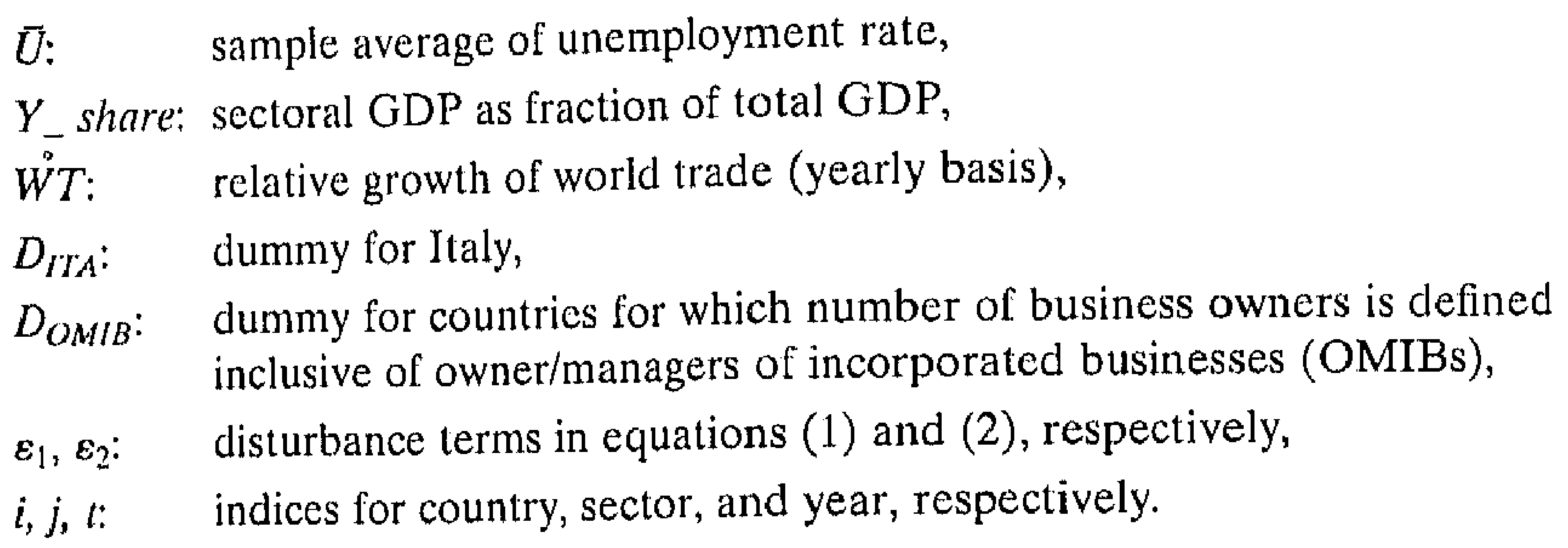

The variables $E, E^{*}$ and $Y$ are defined at the sectoral level and $Y C A P$ and $U$ are defined at the macro level. In the current article business ownership is defined to include both the self-employed (the unincorporated as well as the incorporated) and the unpaid family workers. More details about this definition and the data sources used are given in section 3 . In the remainder of the current section we will describe the three equations in the model in some detail. A more elaborate discussion can be found in Carree et al. (2002). Because the concept of an 'equilibrium' rate of business ownership is central to the model, we start with equation (3).

\section{Equilibrium Business Ownership Equation (3)}

The (sectoral) equilibrium business ownership rate is assumed to be a function $f$ of (macro) economic development as measured by $Y C A P_{i r}$. For low levels of economic development, we expect the function $f$ to be declining. Several authors (e.g. Kuznets, 1971; Schultz, 1990) have reported a negative relationship between economic development and the business ownership (self-employment) rate. Their studies use a large cross-section of countries with a wide variety in the stage of economic development. There is a series of reasons for the decline of selfemployment, and of small business presence in general, during the early phases of industrialization. Chandler (1990) discusses the importance of investment in production, distribution, and management needed to exploit economies of scale and scope during the period after the second industrial revolution of the second half of the 19 th century. It was a period of relatively well-defined technological trajectories, of stable demand and of seemingly clear advantages of diversification.

For high levels of economic development the function $f$ may be increasing. Acs et al. (1994) report that a majority of OECD countries experienced an increase in the self-employment rate during the 1970 s and 1980s. Further evidence of a recent increase in self-employment in many OECD countries appears from EIM's data set COMPENDIA. For instance, for the UK, the number of nonagricultural self-employed (including the incorporated self-employed) as a fraction of total labour force increased from $7.8 \%$ in 1972 to $10.5 \%$ in 2000 , and in the USA this fraction increased from $8.0 \%$ to $10.0 \%$ in the same period (see Van Stel, 2003).

There are several reasons for the revival of small business and self-employment in western economies. First, the last 30 years can be considered a period of industrial restructuring away from traditional manufacturing industries and towards 
Van Stel and Carree: Business Ownership and Sectoral Growth

the electronics, software and biotechnology industries. Jensen (1993) uses the term 'Third Industrial Revolution' to describe this development. Small firms play an important role in these new industries. Second, new technologies have reduced the importance of scale economies in many sectors. This increases the comparative advantage of small firms relative to large firms (see for example Meredith, 1987). Third, from a certain level of economic development onwards, higher income and wealth increase consumer demand for variety (see Jackson, 1984) creating new market niches. Fourth, self-employment has become more highly valued as an occupational choice. This 'supply side' reason may be derived from a supposed hierarchy of human motivations, ranging from physical needs at the bottom to self-realization at the top (Maslow, 1970). Once the main material needs have been satisfied, a still higher level of prosperity will induce a growing need for self-realization. Because it provides more autonomy and independence, entrepreneurship then becomes more highly valued as an occupational choice than at lower income levels.

Based on these trends in self-employment (business ownership), we expect the equilibrium relation to be $U$-shaped (first declining and then rising business ownership rates). However, we will also consider L-shaped relationships (ownership rates continuously declining towards an asymptotic minimum rate). ${ }^{1}$ We have chosen a parametric approach and have used four different equilibrium functions, two of which are U-shaped and two of which are L-shaped. These are given in equations (3a) through (3d). For ease of presentation we do not show the correction factor $\left(1+b_{O M I B} D_{O M I B}\right)$.
(3a) $E_{i j l}^{*}=\alpha+\beta Y C A P_{i t}+\gamma Y C A P_{i t}^{2}$
Quadratic
(3b) $E_{i j t}^{*}=\alpha-\beta \frac{Y C A P_{i i}}{Y C A P_{i t}+1}$
Inverse
(3c) $E_{i j t}^{*}=\alpha+\beta \ln (Y C A P+1)_{i t}+\gamma \ln ^{2}(Y C A P+1)_{i t}$
Log-Quadratic
(3d) $E_{i j t}^{*}=\alpha-\beta \frac{\ln (Y C A P+1)_{i t}}{\ln (Y C A P+1)_{i t}+1}$
Log-Inverse

The equilibrium rate of business ownership equals $\alpha$ when GDP per capita $(Y C A P)$ is zero in each of the four equations (3a) through (3d). In equation (3a) the relation between the level of development and the equilibrium rate of business ownership is quadratic. We expect $\beta$ to be negative as initially economic development is negatively correlated with the business ownership rate. This decline is expected to become smaller over time, so $\gamma$ is expected to be positive. The minimum of the $U$-shaped curve is reached for GDP per capita equal to $-\beta / 2 \gamma$. Another U-shaped relation can be found in equation (3c). Again we expect $\beta$ to be negative and $\gamma$ to be positive. In this log-quadratic case the rise of the curve after the minimum has been reached is less steep than the decline beforehand. Equations ( $3 b$ ) and (3d) give L-shaped equilibrium relations. The equilibrium rate is predicted to decline from $\alpha$ to $\alpha-\beta$ as the level of economic development rises from zero to high levels. We call this equilibrium relation the 


\section{International Small Business Journal 22(4)}

inverse and log-inverse cases. We compare the four different equilibrium functions on the basis of the explanatory powers in equations (1) and (2). That is, we compare the extent to which the change in the rate of entrepreneurship and the sectoral growth rate can be explained from deviations of the actual business ownership rate from the equilibrium business ownership rate.

The functional form of $Y C A P$ in equation (3) is multiplied by a factor $\left(1+b_{O M I B}\right.$ $\left.D_{O M I B}\right)$. This correction is necessary because the self-employment definitions in our data set vary across countries. In section 3 we will go into detail about these differences in definition. Summarized, one group of countries have self-employed defined as individuals inclusive of owner-managers of incorporated businesses (OMIBs) and other countries have a definition exclusive of OMIBs. It is clear that this creates an upward bias for the first group of countries as regards the number of self-employed. As these differences in definition are likely to (erroneously) affect the estimated equilibrium functions, we apply the raise-factor $\left(1+b_{O M I B} D_{O M I B}\right)$. The implicit assumption is that for a given sector the number of OMIBs as a fraction of the total number of business owners is constant for all levels of economic development. Obviously, the estimated $b_{O M I B}$ should be positive.

\section{Business Ownership Equation (1)}

The dependent variable in equation (1) is the growth in the fraction of business owners (self-employed and unpaid family workers) in total sector employment in a period of four years. The first explanatory variable in the equation, which has the parameter $b_{1}$ assigned to it, is an error correction variable describing the difference between the equilibrium and the actual rate of business ownership (at sector level) at the start of the period. The parameter $b_{1}$ is expected to have a positive sign. There are several forces in market economies that may contribute to a process of adapting towards the equilibrium. An abundance of self-employed will lead to low profits and lack of desire to continue family business given that the government does not provide extraordinary support measures to selfemployed. A relative shortage of self-employed may indicate entrepreneurial opportunities that will lead to high (net) entry rates given that the government regulations do not result in high barriers to potential entrepreneurs. The existence of a sound entrepreneurial climate and a well-developed (venture) capital market are instrumental in this respect.

The second explanatory variable is the lagged unemployment rate acting as a push factor for business ownership. ${ }^{2}$ The expected sign of the parameter $b_{2}$ is positive. The third explanatory variable is the sectoral share in GDP. It is likely that scale advantages rank as an important competitive advantage in a sector in case the sectoral share in an economy is relatively high. Opportunities for new small ventures may be less present in later stages of the life cycle of industries in which scale economies in production or $R \& D$ have become key sources of competitive strength (see for example Klepper, 1996). Hence, the expected sign of parameter $b_{3}$ is negative. Finally, we follow Carree et al. in incorporating a dummy for Italy. Italy, especially Northern Italy, is exceptional in the sense that a relatively high value of GDP per capita is combined with a high and rising selfemployment rate. ${ }^{3}$ 
Van Stel and Carree: Business Ownership and Sectoral Growth

\section{Economic Growth Equation (2)}

The dependent variable in equation (2) is sectoral economic growth, measured as the relative change in sectoral gross domestic product in a four-year period. The first determinant of sectoral growth is the (absolute) deviation of the actual rate of business ownership from the equilibrium rate of business ownership at the start of the period. The deviation is expected to have a negative impact on growth, or $c_{1}<0$. A shortage of business owners is likely to diminish competition with detrimental effects for static efficiency and competitiveness of the national economy. It will also diminish variety, learning and selection and thereby harm dynamic efficiency (innovation). On the other hand, a glut of self-employment will cause the average scale of operations to remain below optimum. It will result in large numbers of marginal entrepreneurs, absorbing capital and human energy that could have been allocated more productively elsewhere.

The second determinant is the (economy-wide) level of per capita income at the start of the period. It allows us to correct for the convergence hypothesis of countries. Countries lagging behind in economic development may show faster economic growth than more highly developed countries because they can profit from modern technologies developed in these countries. The expected sign of the parameter $c_{2}$ is negative. Similarly, we include the sectoral share of GDP to capture regression-to-the-mean effects at a sectoral level. Countries in which a certain sector is already quite large are expected to be confronted with less sectoral output growth than countries in which a sector has a smaller share of the economy. The parameter $c_{3}$ is also expected to be negative. The fourth determinant is (current and lagged) growth of world trade. Value added growth of exporting firms is dependent on the developments in world trade. The hypothesized effect of growth of world trade is positive, or $c_{4}, c_{5}, c_{6}>0$. This holds especially for manufacturing as there are, in general, more exporting firms in manufacturing compared to services.

\section{Data}

In this section we deal with the data used in the current article. The section is split up in two parts. First, we discuss the sectoral classification and the required sectoral variables number of business owners, total employment and real value added. Second, we provide an overview of definitions and sources for the variables, either at the sectoral level or at the macro level.

\subsection{Sectoral Data}

We estimate the model for the two main private sectors in a modern economy: manufacturing and services. For these sectors we need data on the number of business owners, total employment and real value added. We have collected these variables for 21 OECD countries for the years 1970-98, as far as the data were available according to uniform definitions. This has resulted in the so-called 'BLISS Oeso Sectoraal' data set, which is operated by EIM. The main data source for 'BLISS Oeso Sectoraal' is OECD National Accounts 1983-1995, Detailed Tables. Where possible, missing data are supplied from other sources. 
International Small Business Journal 22(4)

Below we describe the sector classification used in the data set and describe the above-mentioned variables in some more detail.

Sectoral Classification The sector manufacturing is a one-digit industry in $O E C D$ National Accounts. For services four one-digit industries in the $O E C D$ National Accounts have been aggregated: (1) Wholesale and retail trade, restaurants and hotels; (2) Transport, storage and communication; (3) Finance, insurance, real estate and business services; (4) Community, social and personal services. We realize that our definition of the service sector is very broad. The four underlying sectors may be substantially different in structure, so ideally we would want to distinguish between these sectors. However, the composition of these four underlying sectors is quite different for different countries, as is visible in the numerous country notes on this matter to the statistical tables in the $O E C D$ National Accounts. ${ }^{4}$ Hence, we cannot compare the numbers of business owners in the four underlying service sectors between different countries. These differences in composition do not apply to the aggregate data of the four underlying sectors. Therefore, despite its limitations, we prefer to work with the broad definition of the service sector. ${ }^{5}$

Number of Business Owners Collecting harmonized data on the number of business owners at sectoral level for a large number of countries and over a long period of time is not easy for at least three reasons. ${ }^{6}$ First, business owners (selfemployed) are not defined uniformly across countries. In some countries ownermanagers of incorporated businesses (OMIBs) are counted as self-employed whereas in other countries they are counted as employee. This is because formally an owner-manager of an incorporated business is an employee of his or her own firm. The different statistical treatment results from a different set-up of labour force surveys in different countries. ${ }^{7}$ Second, the big interest for entrepreneurship dates only from recent times. This is the reason that consistent measuring of the self-employed also dates from recent times. For some countries reliable data on the number of self-employed are not available, especially for early years and at a sectoral level. Third, and directly related to the second problem, in some countries major revisions in the way of measuring the selfemployed have taken place in the past. Hence, for these countries numbers of self-employed are not readily comparable over time.

From the description above it becomes clear that we cannot measure the number of self-employed in a uniform fashion for all the 21 countries and for all years in our sample period. Instead, we have made definitions as uniform as possible and work with an unbalanced panel. ${ }^{8}$ We end up with two groups of countries, using different self-employment definitions. This is explained below.

Three Types of Self-employed Based on legal status, self-employed individuals may be split up in three different types: unincorporated self-employed, incorporated self-employed, and unpaid family workers. For each group we have to decide whether or not we want to include them in our self-employment definition. The most common group of self-employed individuals are the 'unincorporated 
Van Stel and Carree: Business Ownership and Sectoral Growth

self-employed' and this group is obviously included in our self-employment count. We also want to include the 'incorporated self-employed' in our count because they are not fundamentally different from the unincorporated selfemployed, as far as 'entrepreneurial spirit' is involved: both types of selfemployed have chosen to 'be their own boss'. However, as mentioned earlier, in some countries the incorporated self-employed are treated as employee in the statistical tables, and for those countries it is not possible to measure their numbers. Because we include the incorporated self-employed in our definition, we generally speak of 'business owners' throughout this article (in order to distinguish from 'self-employed' which is often understood to include only the unincorporated self-employed).

As far as 'unpaid family workers' are concerned, we would rather not include them in our self-employment count. Family workers who work in a family member's firm often have little influence on the 'entrepreneurial' decisions taken. Usually they would not start a business in case the business-owning family member would not run one already. Therefore, we would have liked not to include them in our count of self-employed. However, although there is information at the macro level about the proportions of unpaid family workers in total self-employed in various countries (see the various issues of the OECD Labour Force Statistics), ${ }^{9}$ there is no information about these proportions at the sectoral level. Because sectoral self-employment data in OECD National Accounts are inclusive of unpaid family workers and we cannot (in a plausible way) exclude the unpaid family workers from the available figures, we were left no choice but to include them in our self-employment count.

Definitions As mentioned earlier, the way in which the self-employed are defined in $O E C D$ National Accounts is different across countries. Specifically, in some countries the owner-managers of incorporated businesses are counted as self-employed and in other countries they are counted as employee. We do not correct for the difference in definitions in our data, as we do not dispose of country- and sector-specific information about the proportions of incorporated/ unincorporated self-employed. Instead, we correct for the differences in our model, by means of a so-called OMIB-dummy.

For the construction of the OMIB-dummy, we must know which countries use the narrow definition of self-employed (excluding the incorporated selfemployed), and which countries use the broader one (including the incorporated self-employed). In OECD Employment Outlook June 2000, the countries that use the narrow definition and the ones that use the broad definition are given. That is, the definitions as applied in OECD Labour Force Statistics are mentioned. In principle, the definition used in LFS is also the definition used in OECD National Accounts. But this is not necessarily true for all countries. Based on (1) a comparison between the total number of non-agricultural self-employed (including unpaid family workers) according to OECD Labour Force Statistics and $O E C D$ National Accounts; (2) the definition used in each country in OECD Labour Force Statistics as reported by OECD Employment Outlook June 2000, p. 158 ; (3) the country-notes in OECD National Accounts 1983-1995; we have 


\section{International Small Business Journal 22(4)}

been able to distinguish two groups of countries in our dataset: countries using a broad self-employment definition (including OMIBs) and countries using a narrow definition (excluding OMIBs). The countries having a self-employment definition including OMIBs are Belgium, Denmark, France, West-Germany, Greece, Ireland, Italy, Portugal, Spain, UK, USA and New Zealand. The countries having a self-employment definition excluding OMIBs are Austria, Finland, Netherlands, Sweden, Iceland, Norway, Japan, Canada and Australia. In terms of equation (3), the value of $D_{O M I B}$ is 1 for the first group of countries and 0 for the second group. ${ }^{10}$

Supplementary Sources and Corrections As mentioned earlier, the main source for the sectoral data is OECD National Accounts 1983-1995.11 The number of self-employed (in persons) is derived from country tables 15: employment by kind of activity, as the difference between employment of all persons and employment of employees. Where possible, missing data (including the years 1996-8) are supplied from various other sources, including OECD Labour Force Statistics and $O E C D$ National Accounts 1988-98. Corrections are made to ensure that data from different sources correspond. In some cases country-specific data sources are used to make data comparable with other countries. For example, in $O E C D$ National Accounts the data for the Netherlands are expressed in man-years instead of persons. Therefore, we used information from the Dutch national accounts (published by Statistics Netherlands), to obtain a time series in persons. Also, for the USA, we constructed a series inclusive of OMIBs, making use of information from The State of Small Business, issues 1986 and 1996.

Sectoral business ownership data are reported in Table 1 . Greece and Italy have the highest business ownership rates (1998) for manufacturing, while the Scandinavian countries and the USA have relatively low business ownership rates. Strong increases of the business ownership rate in manufacturing during the period 1970-98 are found for Ireland, UK, USA, Canada, Australia and New Zealand, while Denmark, France, Norway, and especially Japan experienced strong decreases in business ownership rates during this period. Belgium, Greece, Italy, Portugal and Spain have the highest business ownership rates (1998) for services, while relatively low rates are found for the Netherlands, Sweden, Norway, the USA and Australia. The high proportions of self-employed for the former five countries are partly explained by the relatively high numbers of unpaid family workers in these countries. According to Table 4.2 of $O E C D$ Employment Outlook July 1992, the proportion of unpaid family workers in nonagricultural civilian employment in 1990 varies from $3.4 \%$ (Belgium) to 5.4\% (Greece) for these countries. For comparison, this proportion was $0.2 \%$ for the USA and Canada in 1990. Strong increases in the business ownership rate during the period 1970-98 are again found for the UK, Canada and New Zealand, while Denmark, France and Japan also experienced strong declines in business ownership rate for the service sectors.

Total Employment Data on total employment (in persons) are also obtained from OECD National Accounts 1983-1995 (country tables 15: employment of all 
Van Stel and Carree: Business Ownership and Sectoral Growth

Table 1. Sectoral Business Ownership Rates for 21 OECD Countries, 1970-1984-1998

\begin{tabular}{|c|c|c|c|c|c|c|}
\hline \multirow[t]{2}{*}{ Country } & \multicolumn{3}{|c|}{ Manufacturing } & \multicolumn{3}{|c|}{ Services } \\
\hline & 1970 & 1984 & 1998 & 1970 & 1984 & 1998 \\
\hline Austriab & $0.051^{1976}$ & 0.044 & 0.040 & $0.166^{1976}$ & 0.141 & 0.138 \\
\hline Belgium ${ }^{a}$ & 0.057 & 0.062 & 0.065 & 0.309 & 0.280 & 0.283 \\
\hline Denmark $^{\mathrm{a}}$ & 0.067 & 0.048 & 0.032 & 0.214 & 0.173 & 0.144 \\
\hline Finland ${ }^{\mathrm{b}}$ & 0.031 & 0.028 & 0.027 & 0.133 & 0.145 & 0.138 \\
\hline France $^{\mathbf{a}}$ & 0.062 & 0.049 & 0.041 & 0.238 & 0.171 & 0.138 \\
\hline West-Germanya & 0.054 & 0.042 & 0.049 & 0.220 & 0.165 & 0.176 \\
\hline Greece $^{\mathrm{a}}$ & $0.320^{1972}$ & 0.300 & 0.307 & $0.359^{1972}$ & 0.349 & 0.335 \\
\hline Ireland ${ }^{\mathrm{a}}$ & 0.038 & 0.048 & 0.078 & $N / A$ & N/A & N/A \\
\hline Italy ${ }^{\mathbf{a}}$ & 0.139 & 0.155 & 0.164 & 0.425 & 0.459 & 0.437 \\
\hline The Netherlands ${ }^{b}$ & 0.043 & 0.045 & 0.053 & 0.165 & 0.131 & 0.123 \\
\hline Portuga|a & $0.056^{1974}$ & 0.051 & 0.055 & 0.365 & 0.324 & 0.381 \\
\hline Spain ${ }^{a}$ & $0.089^{1972}$ & 0.123 & 0.123 & $\left.0.4\right|^{1972}$ & 0.398 & 0.314 \\
\hline Sweden ${ }^{b}$ & 0.029 & 0.027 & 0.031 & 0.159 & 0.107 & 0.124 \\
\hline$U^{\mathrm{a}}$ & $0.019^{1972}$ & 0.033 & 0.059 & $0.133^{1972}$ & 0.150 & 0.158 \\
\hline |celand & 0.048 & 0.026 & 0.044 & 0.175 & 0.133 & 0.138 \\
\hline Norwayb & 0.051 & 0.037 & 0.032 & 0.126 & 0.106 & 0.093 \\
\hline USA $^{\mathrm{a}}$ & 0.022 & 0.030 & 0.037 & 0.117 & 0.114 & 0.103 \\
\hline Japan & 0.153 & 0.120 & 0.070 & 0.265 & 0.200 & 0.137 \\
\hline Canadab & $0.029^{1976}$ & 0.032 & 0.040 & $0.097^{1976}$ & 0.105 & 0.130 \\
\hline Australia $^{\mathrm{b}}$ & 0.039 & 0.051 & 0.089 & 0.119 & 0.131 & 0.123 \\
\hline New Zealanda & $0.072^{1972}$ & 0.080 & 0.127 & $0.135^{1972}$ & 0.140 & 0.157 \\
\hline Average & 0.070 & 0.068 & 0.075 & 0.217 & 0.196 & 0.189 \\
\hline
\end{tabular}

Source: 'BLISS Oeso Sectoraal'.

Note: business ownership rates are per total sector employment. Except for the USA, business owners include unpaid family workers. Labels ${ }^{a}$ and $b$ indicate that owner/managers of incorporated businesses are included $\left(^{a}\right)$ or excluded $\left({ }^{b}\right)$. In case data for the year 1970 are not available, the first year available in the data set is reported.

persons). Total employment includes self-employed (including OMIBs and unpaid family workers) as well as employees. Again, where possible, missing data are obtained from other sources, including OECD Labour Force Statistics and the Dutch national accounts.

Real Value Added Sectoral data on real value added are obtained from $O E C D$ National Accounts 1983-1995, country tables 12: gross domestic product by kind of activity. The value added data are transformed into data expressed in millions of purchasing power parities per US $\$$ at 1990 prices. This enables valid comparison of value added between countries and over time. Again, where possible, missing data are obtained from various other sources, including $O E C D$ Stan, $O E C D$ Statistical Compendium (on CD-ROM), and, for Portugal, unoficial statistics from the Bank of Portugal. ${ }^{12}$ 


\subsection{Model Variables and Data Sources}

The variables incorporated in the model have the following definitions and sources.

E: $\quad$ sectoral business ownership rate: number of business owners in sector as a fraction of total employment in sector. Counts of number of business owners and total employment are described in section 3.1.

$Y: \quad$ sectoral GDP in purchasing power parities per US $\$$ in 1990 prices. This variable is described in section 3.1.

YCAP: $\quad$ per capita GDP in purchasing power parities per US $\$$ in 1990 prices (macro level). The underlying variables gross domestic product and total population are from OECD National Accounts, Detailed Tables, and from $O E C D$ Labour Force Statistics, respectively. GDP is measured in constant prices. Furthermore, purchasing power parities of 1990 are used to make the monetary units comparable between countries.

$U: \quad$ (standardized) unemployment rate. This variable measures the number of unemployed as a fraction of total labor force. The labor force consists of employees, self-employed persons, unpaid family workers, military and unemployed persons. The main source for this variable is $O E C D$ Main Economic Indicators. Some missing data on the number of unemployed have been filled up with help of data from the OECD Labour Force Statistics and the Yearbook of Labour Statistics from the International Labour Office.

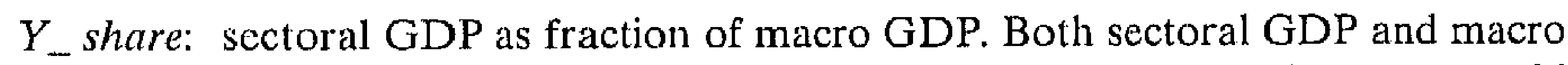
GDP are taken from OECD National Accounts 1983-1995, country tables 12: gross domestic product by kind of activity. We correct for different value added definitions at sectoral level in different countries, i.e., market prices, factor costs, or base prices. The differences result from a different statistical treatment of the items import duties, value added tax, and other indirect taxes. For some countries these items are ascribed to sectors, while for other countries, they are not. We correct for this by taking GDP exclusive of these three items (i.e. the item 'Subtotal') as denominator of $Y_{-}$share.

$\Delta W T: \quad$ growth of world trade (yearly basis). These data are taken from Appendix A4 ('Kerngegevens 1970-2002') of the publication Central Economic Plan (CEP) 2001, item 'relevante wereldhandel', by CPB Netherlands' Bureau for Economic Policy Analysis.

$D_{I T A}$ : dummy for Italy: this variable has value one for Italy, and zero otherwise.

$D_{O M I B}$ : dummy for countries defining the number of business owners inclusive of owner-managers of incorporated businesses (OMIBs): this variable gets value one for the countries Belgium through New Zealand (as mentioned in section 3.1), and value zero for the remaining countries.

\section{Results}

The current section is split up in two parts. In the first part we present separate results for manufacturing and services. We also discuss the methods employed to compute the regression models. In the second part we present a model where 
Van Stel and Carree: Business Ownership and Sectoral Growth

business ownership rates in manufacturing and services, as well as sector structure, are assumed to simultaneously explain growth at the macro level (growth of GDP per capita).

\section{I Methods and Sector Results}

Equations (1) and (2) are estimated successively. For a given specification of $E^{*}$ (equation $3 a, 3 b, 3 c$ or $3 d$ ), we substitute the expression into equation (1). This leads to an expression that is nonlinear in the parameters. Therefore we estimate the regression equation using non-linear least squares. ${ }^{13}$ After having estimated equation (1), we are able to compute $E^{*}$, and hence $\left|E^{*}-E\right|$, using the parameter estimates of the equilibrium function (3). After computing $\left|E^{*}-E\right|$, we are able to estimate equation (2), using OLS.

When estimating the model, we weight observations with population. We consider larger countries such as the US and Japan to be more important in establishing the relationship between business ownership and economic growth than small countries like New Zealand and Iceland. Weighting with population (in the year t-4) implies that all variables (including constants and dummies) are multiplied with the square root of population before the least squares procedure is run. A more detailed description of the weighting of observations can be found in Carree et al. (2002: 286). Both for manufacturing and services, the regressions are computed using unbalanced panels. This is caused by missing data for certain countries and years in our sectoral database. Furthermore, as in Carree et al., uneven years are removed. ${ }^{14}$ Our sample contains 245 observations for the manufacturing sector and 231 observations for services. For the exact construction of these samples we refer to the appendix. The estimation results are presented in Tables 2 and 3.

\section{Equilibrium Equation (3)}

In Tables 2 and 3 estimation results are given for the four different specifications of the sectoral equilibrium rate of business ownership (3a)-(3d). Based on likelihood ratio tests we try to identify which specification fits the data best. To test the quadratic specification versus the inverse specification, we estimate an additional equation (1), where the equilibrium function is now specified as $E_{i j t}^{*}=\alpha+\beta Y C A P_{i t}+\gamma Y C A P_{i t}^{2}+\delta Y C A P_{i t} /\left(Y C A P_{i t}+1\right)$. The quadratic and inverse specifications are special cases of this (artificial) function: the quadratic equilibrium function corresponds to $\delta=0$, while the inverse specification corresponds to $\beta=\gamma=0$. In other words, the quadratic and inverse models are nested in the model and, hence, standard likelihood ratio tests apply. This holds analogously for the log-quadratic versus the log-inverse model. The LR test statistics are given in the tables.

For manufacturing both null hypotheses $\delta=0$ and $\beta=\gamma=0$ cannot be rejected. This means that $U$-shaped equilibrium functions cannot be distinguished from $\mathrm{L}$-shaped functions in a statistical sense. The inverse specification has the highest adjusted $\mathrm{R}^{2}$ values, although the differences are small. The implied asymptotic value of 0.04 for this specification seems plausible. For services the likelihood ratio tests point in the direction of a U-shape: the null hypothesis $\delta=0$ is not 
International Small Business Journal 22(4)

Table 2. Estimation Results Model (1)-(2)-(3) Manufacturing (245 observations)

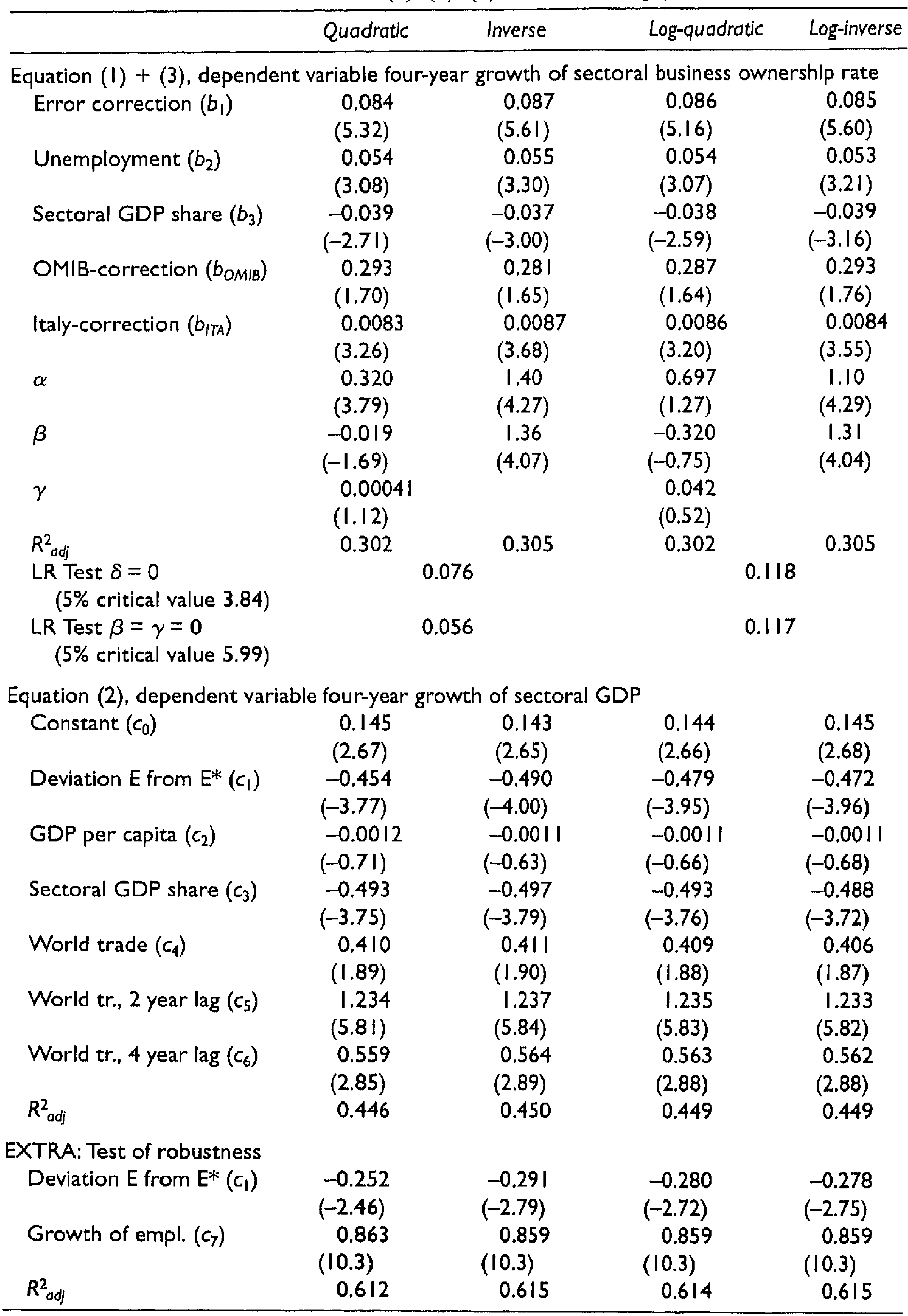

Note: $t$-values in parentheses. The extra equation uses the same control variables as equation (2). 
Van Stel and Carree: Business Ownership and Sectoral Growth Table 3. Estimation Results Model (1)-(2)-(3) Services (231 observations)

\begin{tabular}{|c|c|c|c|c|}
\hline & Quadratic & Inverse & Log-quadratic & Log-inverse \\
\hline \multicolumn{5}{|c|}{ Equation $(1)+(3)$, dependent variable four-year growth of sectoral business ownership rate } \\
\hline \multirow{2}{*}{ Error correction $\left(b_{1}\right)$} & 0.164 & 0.162 & 0.162 & 0.159 \\
\hline & $(9.11)$ & $(8.98)$ & $(9.01)$ & $(8.79)$ \\
\hline \multirow[t]{2}{*}{ Unemployment $\left(b_{2}\right)$} & 0.111 & 0.093 & 0.106 & 0.088 \\
\hline & $(4.13)$ & $(3.62)$ & $(3.95)$ & $(3.45)$ \\
\hline \multirow[t]{2}{*}{ Sectoral GDP share $\left(b_{3}\right)$} & -0.003 & 0.014 & -0.001 & 0.016 \\
\hline & $(-0.14)$ & $(0.94)$ & $(-0.04)$ & $(1.04)$ \\
\hline \multirow[t]{2}{*}{ OMIB-correction (b $\left.b_{O M \mid B}\right)$} & 0.130 & 0.307 & 0.129 & 0.383 \\
\hline & $(0.99)$ & $(1.15)$ & $(0.91)$ & $(1.13)$ \\
\hline \multirow[t]{2}{*}{ Italy-correction $\left(b_{\mid T A}\right)$} & 0.048 & 0.047 & 0.048 & 0.046 \\
\hline & $(9.21)$ & $(8.95)$ & $(9.16)$ & $(8.77)$ \\
\hline \multirow[t]{2}{*}{$\alpha$} & 0.556 & 1.87 & 1.94 & 1.33 \\
\hline & $(4.80)$ & $(5.13)$ & $(3.60)$ & $(4.42)$ \\
\hline \multirow[t]{2}{*}{$\beta$} & -0.050 & 1.92 & -1.22 & 1.73 \\
\hline & $(-4.83)$ & $(5.29)$ & $(-3.25)$ & (4.64) \\
\hline \multirow[t]{2}{*}{$\gamma$} & 0.0014 & & 0.203 & \\
\hline & $(4.04)$ & & $(2.88)$ & \\
\hline$R_{o d j}^{2}$ & 0.402 & 0.385 & 0.398 & 0.377 \\
\hline $\begin{array}{l}\text { LR Test } \delta=0 \\
\qquad(5 \% \text { critical value } 3.84)\end{array}$ & \multicolumn{2}{|c|}{0.369} & \multicolumn{2}{|c|}{3.33} \\
\hline $\begin{array}{l}\text { LR Test } \beta=\gamma=0 \\
\quad(5 \% \text { critical value } 5.99)\end{array}$ & \multicolumn{2}{|c|}{7.02} & \multicolumn{2}{|c|}{12.2} \\
\hline \multicolumn{5}{|c|}{ Equation (2), dependent variable four-year growth of sectoral GDP } \\
\hline \multirow[t]{2}{*}{ Constant $\left(c_{0}\right)$} & 0.173 & 0.163 & 0.172 & 0.162 \\
\hline & $(4.82)$ & $(4.48)$ & $(4.7 I)$ & $(4.46)$ \\
\hline \multirow[t]{2}{*}{ Deviation $E$ from $E^{*}\left(c_{1}\right)$} & -0.110 & -0.053 & -0.087 & -0.051 \\
\hline & $(-2.39)$ & $(-1.22)$ & $(-1.94)$ & $(-1.16)$ \\
\hline \multirow{2}{*}{ GDP per capita $\left(c_{2}\right)$} & -0.0051 & -0.0047 & -0.0051 & -0.0046 \\
\hline & $(-3.75)$ & $(-3.40)$ & $(-3.66)$ & $(-3.39)$ \\
\hline \multirow[t]{2}{*}{ Sectoral GDP share $\left(c_{3}\right)$} & 0.058 & 0.059 & 0.057 & 0.060 \\
\hline & $(0.73)$ & $(0.74)$ & $(0.7 \mathrm{I})$ & $(0.75)$ \\
\hline \multirow[t]{2}{*}{ World trade $\left(c_{4}\right)$} & -0.302 & -0.303 & -0.302 & -0.303 \\
\hline & $(-2.35)$ & $(-2.34)$ & $(-2.34)$ & $(-2.34)$ \\
\hline \multirow[t]{2}{*}{ World tr., 2 year lag $\left(c_{5}\right)$} & 0.405 & 0.417 & 0.410 & 0.417 \\
\hline & $(3.20)$ & $(3.27)$ & $(3.23)$ & $(3.27)$ \\
\hline \multirow[t]{2}{*}{ World tr., 4 year lag $\left(c_{6}\right)$} & 0.374 & 0.390 & 0.382 & 0.391 \\
\hline & $(3.19)$ & $(3.31)$ & $(3.26)$ & $(3.31)$ \\
\hline$R_{\text {odj }}^{2}$ & 0.788 & 0.783 & 0.786 & 0.782 \\
\hline \multicolumn{5}{|l|}{ EXTRA: Test of robustness } \\
\hline \multirow[t]{2}{*}{ Deviation $E$ from $E^{*}\left(c_{1}\right)$} & -0.051 & -0.0057 & -0.032 & -0.0030 \\
\hline & $(-1.19)$ & $(-0.14)$ & $(-0.76)$ & $(-0.075)$ \\
\hline \multirow[t]{2}{*}{ Growth of empl. $\left(c_{7}\right)$} & 0.542 & 0.559 & 0.549 & 0.559 \\
\hline & $(7.07)$ & $(7.30)$ & $(7.16)$ & $(7.31)$ \\
\hline$R_{o d j}^{2}$ & 0.819 & 0.817 & 0.818 & 0.817 \\
\hline
\end{tabular}

Note: $t$-values in parentheses. The extra equation uses the same control variables as equation (2). 


\section{International Small Business Journal 22(4)}

rejected while the null hypothesis $\beta=\gamma=0$ is. This holds for both types of comparisons: quadratic versus inverse and log-quadratic versus log-inverse. So, after having reached a minimum level, the business ownership rate starts to rise again with increasing wealth (i.e. increasing GDP per capita). For the quadratic specification, the minimum $-\beta / 2 \gamma$ is reached at 18,129 US dollar (1990 prices). The minimum business ownership rate equals 0.099. Based on this analysis, we will discuss the other estimation results for the specifications with the best statistical fit: L-shape for manufacturing (inverse or log-inverse) and $U$-shape for services (quadratic or log-quadratic).

\section{Equation (1)}

From Tables 2 and 3 we see that error-correction processes are statistically significant for both manufacturing and services. However, the speed of adjustment is low: $16 \%$ for services and $9 \%$ for manufacturing. A speed of adjustment of $16 \%$ means that a deviation of the number of business owners from equilibrium at a certain point in time decreases with $16 \%$ in the succeeding four years. The low value of the speed of adjustment is not surprising. The convergence process of the actual business ownership rate towards the equilibrium rate is intrinsically slow because it involves structural changes on the supply side (setting up enterprises, investments in physical and human capital, divestments, etc.) as well as cultural and institutional changes. As some of these processes are especially slow in manufacturing, the lower speed of adjustment for this sector compared to services is not surprising. For instance, it is more difficult to start a business in the manufacturing sector than in the service sector, because on average more start-up capital is required.

We find evidence for the unemployment push hypothesis. For services, every percent point rise in the unemployment rate leads to a rise of 0.11 percent point in the self-employment rate in the succeeding four years. For manufacturing this effect is 0.06 percent point. Again, the smaller effect for manufacturing may be explained by higher set-up costs for starting a new business. A significantly negative sign of sectoral GDP share (parameter $b_{3}$ ) is found only in the case of the manufacturing sector. High shares of manufacturing in a country's economy are associated with subsequently lower business ownership rates. This may reflect the importance of economies of scale in manufacturing.

The estimated correction factor for the number of OMIBs, $b_{O M I B}$, is plausible, both for manufacturing and services. In the equilibrium functions, the number of OMIBs as a proportion of other self-employed (unincorporated self-employed and unpaid family workers) equals 0.28 and 0.13 for manufacturing and services, respectively. The additional (unexplained) rise in business ownership for Italy is supported by our estimations: parameter $b_{I T A}$ is significantly positive. The effect is much stronger for services though: the parameter is about five times higher for services compared to manufacturing.

\section{Equation (2)}

According to the significantly negative estimate of $c_{1}$, deviations between actual and equilibrium business ownership rates come at a cost of foregone growth. The 


\section{Van Stel and Carree: Business Ownership and Sectoral Growth}

effect is stronger for manufacturing than for services. Each percent point difference between $E$ and $E^{*}$ is associated with a loss of 0.5 percent point subsequent growth in value added (on a four-year basis) in manufacturing. For services this effect is only 0.1 percent point. This suggests that deviating from the 'optimal' firm size distribution is more important for manufacturing when compared to services. Either having too few or too many entrepreneurial ventures in manufacturing appears to be more damaging to economic performance than when this occurs in the service sector. When there are too few entrepreneurs this may come at the cost of the rate of radical innovations and, consequently, economic growth. When there are too many entrepreneurs economies of scale may not be benefited from enough. In Figures 1 and 2 it is shown that for manufacturing the number of business owners is generally too low (consistent with a lack of incentives to innovate), while for services the number of business owners is generally too high. The latter observation implies that in many countries there are a lot of 'marginal' entrepreneurs, whose efforts and energy could be allocated more effectively working as wage earners. This is especially true for Italy.

The estimations also find evidence for the convergence of countries: GDP per capita has a negative impact on subsequent growth (parameter $c_{2}$ ), although the effect is significant only for services. For manufacturing there is a regressionto-the-mean effect: the parameter of sectoral GDP-share $\left(c_{3}\right)$ is significantly negative. For services the latter effect is not found. Finally, we find a significant positive impact of the growth of world trade on sectoral growth. Looking at the combined effect (the sum of parameters $c_{4}, c_{5}$ and $c_{6}$ ) the effect is larger for manufacturing. Again, this is not surprising, given the bigger orientation on export in this sector.

Test of Robustness As a test of robustness, we also estimated the sector growth equation with employment growth included as an extra explanatory variable. See the last parts of Tables 2 and 3 . Note that, by and large, we thus measure labour productivity growth instead of production growth. Although $t$-values become lower, the estimates of $c_{1}$ (growth penalty) remain negative. This gives us some confidence about the robustness of the growth penalty. The coefficient of employment growth $c_{7}$ is smaller than one, which suggests decreasing returns to scale. However, this is not necessarily the case. As employment is measured in persons, the low coefficient may reflect a relative increase in part-time workers (compared to full-time workers). This phenomenon may be stronger for services, considering the low value of the estimated coefficient $c_{7}$.

Equilibrium Curves In Figures 1 and 2, we show the equilibrium curves and the actual data for the G7-countries. For the equilibrium curves we choose the specification with the best statistical fit: 'Inverse' for manufacturing and 'Quadratic' for services. For manufacturing, all G7-countries - except for Italy are well below the 'equilibrium' rate. ${ }^{15}$ According to the significant negative parameter estimate of $c_{1}$ in equation (2), these deviations from equilibrium are penalized in the form of lower growth rates. So, apparently, there are too few self-employed in the manufacturing industries. Perhaps the low numbers of 
International Small Business Journal 22(4)

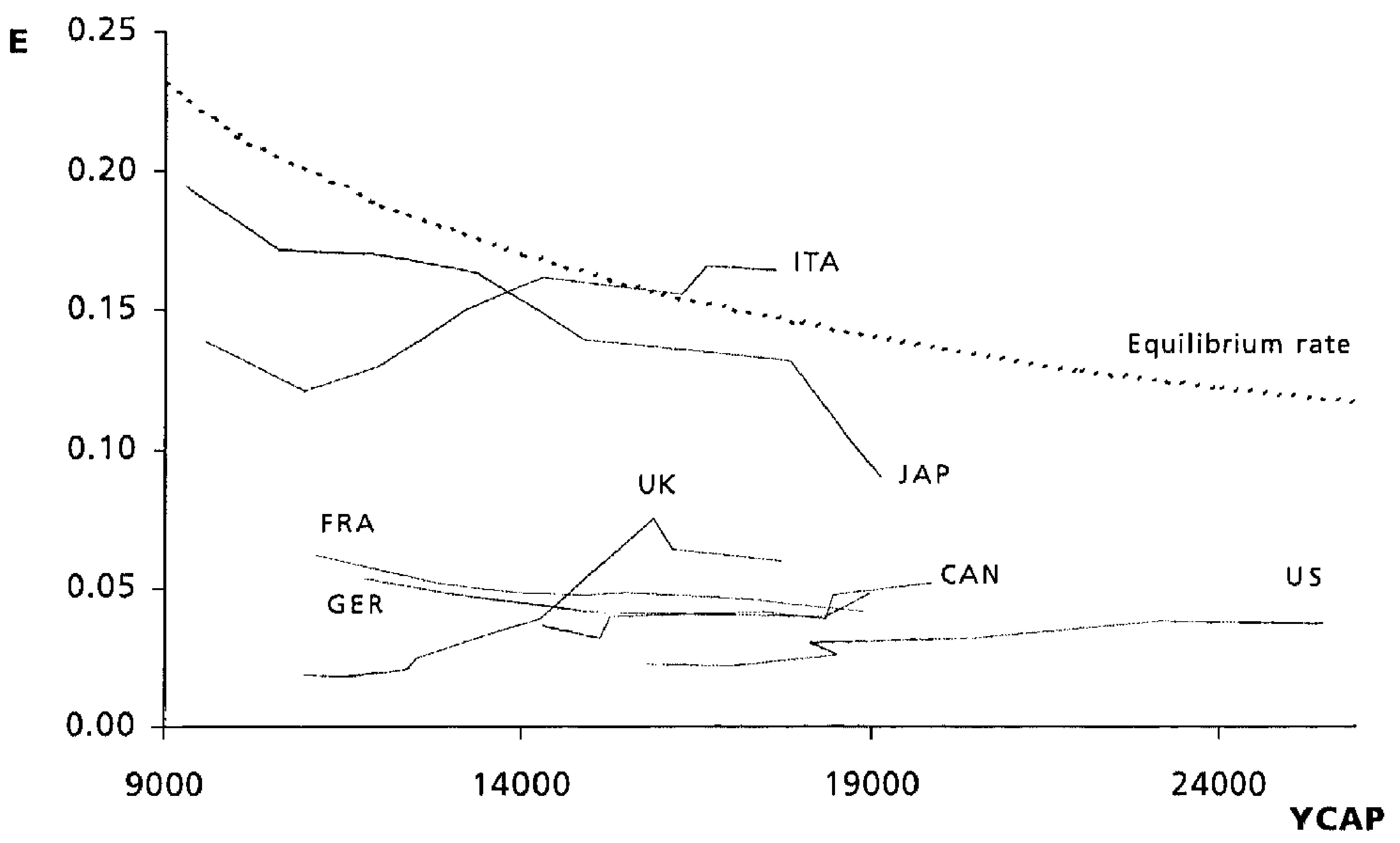

Figure 1. Actual and Equilibrium Business Ownership Rate for G7 Countries, 1970-98, Manufacturing

Note: Actual and equilibrium business ownership rates are per total sector employment. Business owners include unpaid family workers and owner-managers of incorporated businesses. Equilibrium rate according to 'Inverse' specification in Table 2. Data for Japan and Canada are raised by the estimated factor $\left(I+b_{O M I B}\right)=1.281$ to facilitate valid comparison of $E$ and $E^{*}$. Per capita income YCAP expressed in purchasing power parities per US $\$$ at 1990 prices.

competitors and new entrepreneurial initiatives result in a lack of innovation incentives and therefore, in lower growth rates. Japan and Italy have been relatively close to the equilibrium curve. According to our model, the relatively high business ownership rate for manufacturing in these countries has favoured economic growth.

Contrary to manufacturing, the business ownership rates in most of the G7countries are above equilibrium for services, the USA being the exception. The U-curved equilibrium function, which was clearly preferred over an L-shape, does not show in the actual business ownership rate data for the G7-countries. Only the UK and Canada have increasing business ownership rates. Note, however, that most countries still have levels of GDP per capita corresponding to the decreasing part of the curve. That is, they did not yet reach the per capita income corresponding to the minimum level of the parabola. For services, the business ownership rate of Italy lies far above equilibrium. The extremely low scale of operations in Italian service industries appears clearly sub-optimal. It suggests that the majority of these marginal self-employed individuals could work more effectively as wage earners. ${ }^{16}$ 
Van Stel and Carree: Business Ownership and Sectoral Growth

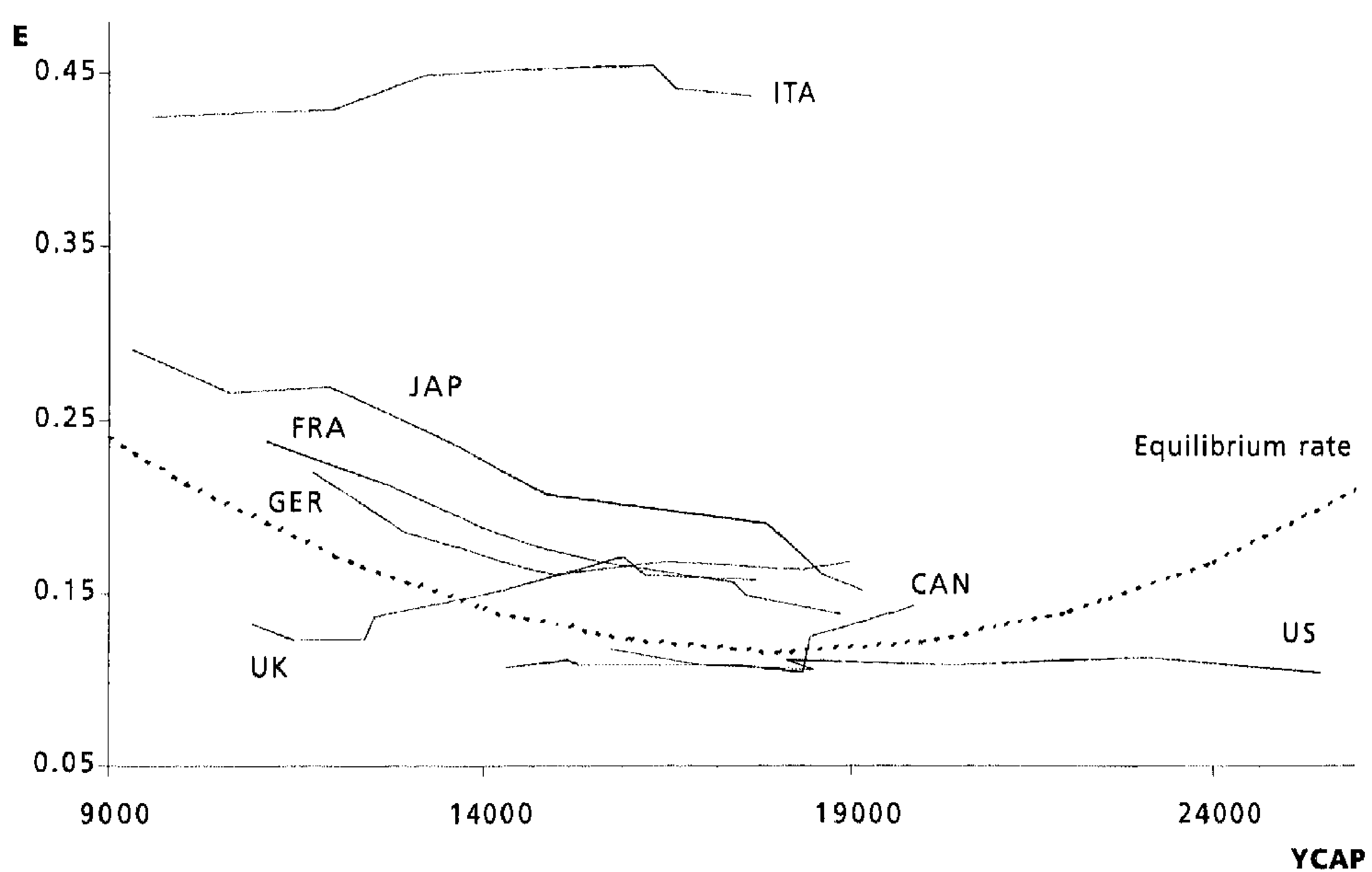

Figure 2. Actual and Equilibrium Business Ownership Rate for G7 Countries, 1970-98, Services

Note: Actual and equilibrium business ownership rates are per total sector employment. Business owners include unpaid family workers and owner/managers of incorporated businesses. Equilibrium rate according to 'Quadratic' specification in Table 3. Data for Japan and Canada are raised by the estimated factor $\left(1+b_{O M I B}\right)=1.130$ to facilitate valid comparison of $E$ and $E^{*}$. Per capita income YCAP expressed in purchasing power parities per US\$ at 1990 prices.

\subsection{Effect on Macro Growth}

In the previous sections we analysed the relationship between business ownership and economic growth for manufacturing and services separately. We related deviations between the actual business ownership rate $E$ and the equilibrium or optimal business ownership rate $E^{*}$ in one sector to value added growth of that same sector. In this section we look at the effect of deviations at the sectoral level to growth at the macro level. In this way we can determine whether deviations in one sector are more harmful to growth than deviations in another sector. We also consider (deviations from the average) sector structure as a possible determinant of economic growth at the macro level. In Table 4 we report the sector shares of manufacturing and services in economy-wide GDP for the 21 countries in our data set, for three years in the period 1970-98.

The Average Sector Structure In order to investigate the effect of sector structure on economic growth we introduce the concept of an average sector structure. Like the sectoral equilibrium business ownership rate equations (3), we 
International Small Business Journal 22(4)

Table 4. Sector Share in Total Economy (GDP) for 21 OECD Countries, 1970-1984-1998

\begin{tabular}{|c|c|c|c|c|c|c|}
\hline \multirow[t]{2}{*}{ Country } & \multicolumn{3}{|c|}{ Manufocturing } & \multicolumn{3}{|c|}{ Services } \\
\hline & 1970 & 1984 & 1998 & 1970 & 1984 & 1998 \\
\hline Austria & 0.23 & 0.23 & 0.23 & 0.40 & 0.46 & 0.49 \\
\hline Belgium & 0.22 & 0.23 & 0.21 & $0.52^{1976}$ & 0.52 & 0.54 \\
\hline Denmark & 0.20 & 0.21 & 0.17 & 0.46 & 0.44 & 0.45 \\
\hline Finland & 0.22 & 0.23 & 0.29 & 0.34 & 0.37 & 0.38 \\
\hline France & 0.25 & 0.24 & 0.22 & 0.41 & 0.47 & 0.51 \\
\hline West Germany & 0.38 & 0.33 & $0.27^{1996}$ & 0.35 & 0.41 & $0.50^{1996}$ \\
\hline Greece & 0.17 & 0.17 & 0.14 & 0.37 & 0.41 & 0.47 \\
\hline Ireland & $0.19^{1976}$ & 0.21 & $0.30^{1994}$ & N.A. & N.A. & N.A. \\
\hline Italy & 0.18 & 0.21 & 0.22 & 0.42 & 0.47 & 0.50 \\
\hline The Netherlands & 0.21 & 0.20 & 0.19 & 0.48 & 0.52 & 0.57 \\
\hline Portugal & 0.21 & 0.23 & 0.26 & 0.48 & 0.43 & 0.48 \\
\hline Spain & 0.23 & 0.23 & 0.21 & N.A. & $0.49^{1986}$ & 0.50 \\
\hline Sweden & 0.24 & 0.23 & 0.25 & 0.37 & 0.39 & 0.42 \\
\hline UK & 0.30 & 0.23 & 0.20 & 0.45 & 0.46 & 0.53 \\
\hline Iceland & $0.23^{1980}$ & 0.20 & 0.16 & $0.39^{1980}$ & 0.42 & 0.44 \\
\hline Norway & 0.23 & 0.15 & 0.11 & 0.49 & 0.46 & 0.44 \\
\hline USA & 0.20 & 0.18 & $0.22^{1996}$ & 0.48 & 0.56 & $0.59^{1996}$ \\
\hline Japan & 0.26 & 0.26 & 0.27 & 0.42 & 0.48 & 0.53 \\
\hline Canada & 0.20 & 0.19 & 0.18 & 0.38 & 0.44 & 0.48 \\
\hline Australia & $0.18^{1974}$ & 0.16 & 0.13 & 0.60 & 0.63 & 0.68 \\
\hline New Zealand & $0.21^{1978}$ & 0.22 & 0.18 & $0.51^{1978}$ & 0.50 & 0.55 \\
\hline Average* & 0.23 & 0.22 & 0.21 & 0.44 & 0.47 & 0.50 \\
\hline
\end{tabular}

Source: EIM, based on OECD.

Note: When 1970 or 1998 data are not available, the earliest or the most recent year available in the data set is reported. *Excluding Ireland and Spain.

choose a specification in which sector structure is dependent on GDP per capita. Because the two sectors manufacturing and services comprise almost all economic activity in most countries, we simply use GDP share of services in a country's total GDP as indicator of sector structure. We choose a log-linear specification for the average sector structure function:

$Y_{-}$share $_{i, \text { services, },}=\varsigma+\eta \ln (Y C A P+1)_{i t}+\varepsilon_{3 i t}$,

where $Y_{-}$share and $Y C A P$ are as defined in section 2, and $\varepsilon_{3}$ is a disturbance term. It is well known that the share of services in an economy rises with GDP per capita. Hence, the expected sign of $\eta$ is positive. As parameter $s$ is interpreted as the share of services when per capita income equals zero, this parameter should also be positive. Equation (4) is estimated as a separate equation (again using weighted least squares) and residuals are interpreted as deviations from the average sector structure. ${ }^{17} \mathrm{Next}$, the absolute values of the residuals are inserted in the macro growth equation as an independent variable. Like deviating from 
an equilibrium business ownership rate, it could be the case that deviating from an average sector structure may hamper economic growth. ${ }^{18}$ However, this is far from certain because countries might also benefit from 'specialization'.

For our macro growth equation we use the equilibrium relations with the best statistical fit found in section 4.1: inverse for manufacturing and quadratic for services. Next we estimate equation (4), to obtain a function for the average industry structure. Finally, the variables thus obtained (deviations for sectoral business ownership rates and industry structure) are used as independent variables in the macro growth equation. This equation reads as follows:

$$
\begin{aligned}
& \frac{\Delta_{4} Y C A P_{i t}}{Y C A P_{i, 1-4}}=c_{0}+c_{1}\left|E_{i, \text { mamuf }, 1-4}^{*}-E_{i, \text { manuf, },-4}\right|+c_{2}\left|E_{i, \text { serv }, 1-4}^{*}-E_{i, \text { serv, },-4}\right|+ \\
& c_{3} \mid Y_{-} \text {share }_{i, \text { serv, },-4}^{*}-Y_{-} \text {share }_{i, \text { serv, } t-4} \mid+c_{4} Y C A P_{i, 1-4}+ \\
& c_{5} W T_{t}+c_{6} W T_{t-2}+c_{7} W T_{t-4}+\varepsilon_{2 i j t}
\end{aligned}
$$

where the subscripts manuf and serv stand for manufacturing and services, respectively, and where the variable $Y_{-}$share ${ }^{*}$ is formed by the fitted values of equation (4). Equation (5) is chosen such that results of our macro growth equation are comparable to the sector results presented earlier. In equation (5) we explain macro-economic growth (growth of GDP per capita) from deviations between actual and equilibrium business ownership rate in both manufacturing and services. Furthermore we include deviations from the average industry structure as an independent variable. Results are presented in Table 5.

In Table 5, the results of the first estimated equation are taken from Tables 2 and 3. Based on these equilibrium functions, deviations between actual and equilibrium business ownership rates are calculated. These deviation variables are used in the third estimated equation, along with the deviation from the average industry structure (residuals of equation [4]). The estimation results of this latter equation are also in Table 5. The statistical fit of the average sectoral GDP-share of services is high with an adjusted $\mathrm{R}^{2}$ of 0.979 . The estimated share of services in macro-GDP rises with per capita income as $\eta$ is estimated to be positive.

Estimation of the macro growth equation (5) results in negative parameter estimates for all three deviation variables. However, absolute $t$-values are around one. ${ }^{19}$ Although they are not significantly different from zero, the fact that all three coefficients are negative provides an indication that deviating from equilibrium business ownership rates or average sector structure might have a negative impact on per capita income growth. Of course, they are no more than indications because $t$-values are low.

\section{Discussion}

In this article we investigate the development of business ownership (selfemployment) rates over time and the effect of business ownership on economic growth, both at the sectoral level. In an earlier exercise, Carree et al. (2002) 
International Small Business Journal 22(4)

Table 5. Estimation Results Model (1)-(3)-(4)-(5) Macro Level

\begin{tabular}{|c|c|c|c|}
\hline & \multicolumn{2}{|c|}{$\begin{array}{l}\text { Monufocturing: Inverse Case, } \\
\text { (245 Observations) }\end{array}$} & $\begin{array}{l}\text { Services: Quodrotic Case, } \\
\text { (231 Observotions) }\end{array}$ \\
\hline \multicolumn{4}{|c|}{ Equation (1) $+(3)$, dependent variable four-year growth of sectoral business ownership rate } \\
\hline \multirow{2}{*}{ Error correction $\left(b_{1}\right)$} & 0.087 & & 0.164 \\
\hline & $(5.6 I)$ & & $(9.11)$ \\
\hline \multirow[t]{2}{*}{ Unemployment $\left(b_{2}\right)$} & 0.055 & & 0.111 \\
\hline & $(3.30)$ & & $(4.13)$ \\
\hline \multirow[t]{2}{*}{ Sectoral GDP share $\left(b_{3}\right)$} & -0.037 & & -0.0027 \\
\hline & $(-3.00)$ & & $(-0.14)$ \\
\hline \multirow[t]{2}{*}{ OMIB-correction (b $\left.b_{O M / B}\right)$} & 0.281 & & 0.130 \\
\hline & (1.65) & & $(0.99)$ \\
\hline \multirow{2}{*}{ Italy-correction $\left(b_{1 T A}\right)$} & 0.0087 & & 0.048 \\
\hline & $(3.68)$ & & $(9.21)$ \\
\hline \multirow[t]{2}{*}{$\alpha$} & 1.40 & & 0.556 \\
\hline & (4.27) & & $(4.80)$ \\
\hline \multirow[t]{2}{*}{$\beta$} & 1.36 & & -0.050 \\
\hline & $(4.07)$ & & $(-4.83)$ \\
\hline \multirow[t]{2}{*}{$\gamma$} & & & 0.0014 \\
\hline & & & $(4.04)$ \\
\hline$R_{\text {odj }}^{2}$ & 0.305 & & 0.402 \\
\hline \multicolumn{4}{|c|}{ Equation (4), dependent variable GDP-share services in macro-GDP (227 observations) } \\
\hline \multirow[t]{2}{*}{$s$} & & 0.011 & \\
\hline & & $(0.32)$ & \\
\hline \multirow[t]{2}{*}{$\eta$} & & 0.171 & \\
\hline & & (13.6) & \\
\hline$R_{\text {odj }}^{2}$ & & 0.979 & \\
\hline \multicolumn{4}{|c|}{ Equation (5), dependent variable four-year growth of GDP per capita (227 observations) } \\
\hline \multirow{2}{*}{ Constant $\left(c_{0}\right)$} & & 0.307 & \\
\hline & & $(3.96)$ & \\
\hline \multirow{2}{*}{\multicolumn{2}{|c|}{ Deviation $E$ from $E^{*}$, manufacturing $\left(c_{1}\right)$}} & -0.248 & \\
\hline & & $(-1.03)$ & \\
\hline \multirow{2}{*}{\multicolumn{2}{|c|}{ Deviation $E$ from $E^{*}$, services $\left(c_{2}\right)$}} & -0.150 & \\
\hline & & $(-0.99)$ & \\
\hline \multirow{2}{*}{\multicolumn{2}{|c|}{$\begin{array}{l}\text { Deviation from 'optimal' industry structure } \\
\left(c_{3}\right)\end{array}$}} & -0.329 & \\
\hline & & $(-1.04)$ & \\
\hline \multirow{2}{*}{ GDP per capita $\left(c_{4}\right)$} & & -0.011 & \\
\hline & & $(-3.64)$ & \\
\hline \multirow[t]{2}{*}{ World trade $\left(c_{5}\right)$} & & -0.444 & \\
\hline & & $(-1.22)$ & \\
\hline \multirow[t]{2}{*}{ World tr., 2 year lag $\left(c_{6}\right)$} & & -0.024 & \\
\hline & & $(-0.067)$ & \\
\hline \multirow[t]{2}{*}{ World tr., 4 year lag $\left(c_{7}\right)$} & & -0.083 & \\
\hline & & $(-0.25)$ & \\
\hline$R_{\text {odj }}^{2}$ & & 0.100 & \\
\hline
\end{tabular}

Note: $t$-values in parentheses. Estimations of equations (4) and (5) include all observations for which data of manufacturing and services are simultaneously available. 
Van Stel and Carree: Business Ownership and Sectoral Growth

presented a two-equation model to analyse the interrelationship between economy-wide business ownership rates and economic development. They apply the model to a data set of 23 OECD countries for the period 1976-96. The article showed empirical evidence for a (slow) error-correction process for business ownership rates: countries with business ownership rates more or less than the 'equilibrium' value for the specific stage of economic development of these countries showed, on average, convergence towards the 'equilibrium'. In addition, it was found that the 'equilibrium' relationship between business ownership rate and stage of economic development (as proxied by GDP per capita) was declining for the larger part of the range of GDP per capita but had the tendency to rise for the highest levels of GDP per capita. The study also provided evidence that countries that had an out-of-equilibrium value of business ownership rate suffered in terms of economic growth foregone.

The analysis performed by Carree et al. (2002) raises an important research question: to what extent do differences in business ownership at the economywide level reflect differences in the sectoral structures of economies or differences in business ownership rates at the sectoral level? It is well known that the average business ownership rate in the service sector is much higher than that in the manufacturing sector. Data in the current article show that the average rate (including unpaid family workers) for OECD countries was almost $20 \%$ in 1984 for the service sector, while it was less than $7 \%$ for the manufacturing sector. This has important consequences for the analysis previously performed. The tendency of business ownership rates to increase may be due just to a shift of economic activity from the manufacturing sector towards the service sector in the course of economic development. As a consequence, the penalty found for deviating from the 'equilibrium' value of (economy-wide) business ownership may really be a penalty for deviating from a certain structural composition of the economy. This study investigates the 'equilibrium' relationship between business ownership rates and economic development, the speed of the error-correction process and the existence (and severity) of the growth penalty when deviating from 'equilibrium' for both the manufacturing sector and the service sector for the OECD countries in the period 1970-98.

The article develops an adjusted two-equation model relating business ownership rates and economic growth rates at the sectoral level. Specific attention in the model is paid to whether national statistical agencies have reported to include owner-managers of incorporated business into the data. Four different types of 'equilibrium' relations between business ownership rate and GDP per capita are investigated, two of which have a U-shape (first declining and then rising ownership rates) and two of which have an L-shape (ownership rates continuously declining towards an asymptotic minimum rate). We have collected data for 21 OECD countries for the years 1970-98, as far as the data were available according to uniform definitions. The data show that, on average for OECD countries, business ownership rates in manufacturing have been largely stable at $7 \%$, while they have, on average, been decreasing for the service sector from $22 \%$ in 1970 to $19 \%$ in 1998. However, in several important industrial economies such as the UK, the USA, Canada and Australia, business ownership in manufacturing has 
International Small Business Journal 22(4)

gone up. Ownership rates in manufacturing remain lower than ownership rates in services though. This confirms that at least part of the increase in the economywide share of business ownership is due to the sectoral shift towards the service sector in developed economies.

Results show that the empirical fit of the four different types of 'equilibrium' relationships is not too different, both for the case of manufacturing and that of services. However, results for the speed of error-correction are hardly affected by which type is chosen. The estimated speed of error-correction for the manufacturing sector is about $8.5 \%$ for a four-year period. This estimated speed is twice as high in the service sector: about $16 \%$. Both in the manufacturing sector and for services there is a positive effect of (lagged) unemployment: countries with high unemployment show higher subsequent business ownership rates both in manufacturing and services. The results show that there is a significant penalty of the business ownership rate deviating from 'equilibrium' for manufacturing for each of the four types of the 'equilibrium' relationship. For the service sector also a negative effect on growth is found, but it is not always significant and it is far smaller than that for manufacturing.

The analysis confirms the empirical evidence provided by Carree et al. (2002) that differences in business ownership rates matter and disappear over time slowly. The general idea behind the model is that there can be both too many and too few businesses. Too many businesses may mean that economies of scale and scope are not benefited enough from and that there are probably many 'marginal' ventures. Too few businesses may imply that there is not enough entrepreneurial activity.

The results presented in the current article make a contribution to the international debate on increasing entrepreneurship as a route to economic growth. For instance, one of the major objectives of the Global Entrepreneurship Monitor research program is to gain more insight into the systematic relationship between entrepreneurship and national economic growth (Reynolds et al., 2002). Based on correlation analysis of nationwide measures of entrepreneurship and economic growth, Reynolds et al. (2002: 6) state that 'evidence continues to accumulate that the national level of entrepreneurial activity has a statistically significant association with subsequent levels of economic growth'.

The current analysis shows that entrepreneurial activity as far as embodied in self-employment rates may benefit economic growth, but is not always a route to growth. Our analysis suggests not only that economies can have too few or too many businesses, but also that the extent to which there are too many or too few businesses varies by sector. In particular, the estimated equilibrium curves suggest that having too few businesses is the more likely problem in manufacturing, while having too many businesses is the more likely problem in the service sector. It would suggest that the economic benefits of government promoting new (and small) business may not only be country-specific, but also sector-specific. Such promotion seems most beneficial in the manufacturing sector of countries with very low business ownership rates (like the Scandinavian countries). It may be counter-productive to have similar promotion in the service sector of countries with very high business ownership rates (like Italy). 
Van Stel and Carree: Business Ownership and Sectoral Growth

\section{Acknowledgement}

This article has been written in the framework of the research programme SCALES (SCientific AnaLysis of Entrepreneurship and SMEs) which is financed by the Dutch Ministry of Economic Affairs. The authors are grateful to Sander Wennekers and two anonymous referees for providing helpful comments on an earlier draft. Martin Carree is grateful to the Royal Netherlands Academy of Arts and Sciences (KNAW) for financial support. Both authors are also affiliated with the Centre for Advanced Small Business Economics (CASBEC) at Erasmus University Rotterdam.

\section{Notes}

1. Carree et al. (2002) concluded that U-shaped functions cannot be statistically discriminated from L-shaped functions.

2. The empirical evidence on the effect of unemployment on business formation is mixed. Evans and Leighton (1989) present evidence that unemployed workers are more likely to enter self-employment than employees. Carree (2002b) finds no effect of unemployment rates on the number of establishment in low entry barrier retail and consumer service industries.

3. We do not include dummies for all countries in the sample. An implication of such a specification is that every country has its own unique equilibrium level. However, this type of country-specific equilibrium level is not the focus of this study, since we are investigating a 'universal' equilibrium function that should be valid for all countries. Also, deviations from country-specific equilibrium levels have quite a different interpretation than deviations from a 'universal' equilibrium level, as the former type of deviation ignores the cross-country variation in business ownership rates.

4. For example, for a number of countries the sub-sector Business services, which is part of sector Finance, etc., is included in Community, social and personal services, see $\operatorname{OECD}(1997 \mathrm{a}: 100,212,351,368,600)$. For some countries the sub-sector Restaurants and hotels, which is part of Wholesale, etc., is included in Community, social and personal services, see OECD (1997a), pp. 100, 148 and 368. For Italy, a distinction between Finance, etc., and Community, social and personal services has not even been made in the statistical tables of $O E C D$ National Accounts. Only aggregate data of these two sectors are included in the tables, see OECD (1997a: 431).

5. A similar problem applies to the one-digit manufacturing sector. In some countries the one-digit sector mining is included in the manufacturing sector. In prevailing cases, we did correct for it with help of data from the Labour Force Statistics. Also, with help of data from other sources, we made a correction in the GDP data for manufacturing to exclude the mining part in these figures.

6. Measurement problems concerning comparability of new firm formation rates across seven economically advanced countries are identified in a special issue of Regional Studies (see Reynolds et al., 1994).

7. See Chapter 5 of OECD Employment Outlook June 2000.

8. This means that the data are not available for the same period of time for all countries and sectors. Instead we work with the maximum amount of data that we were able to collect for each country and sector.

9. In earlier studies that we performed at the macro level, we have in fact used selfemployment data exclusive of unpaid family workers (Carree et al. 2000, 2002). These studies make use of EIM's data set COMPENDIA, see Van Stel (2003).

10. Two remarks concerning the USA are required here. First, the definition in $O E C D$ 


\section{International Small Business Journal 22(4)}

National Accounts for the USA is exclusive of OMIBs. Instead of using these data and classifying the USA in the second group of countries (i.e. excluding OMIBs), we made an exception for the USA and made an approximation of the number of OMIBs based on information from The State of Small Business. The exception was made because we would like to include the number of OMIBs in our definition and we consider the USA too important to settle for a definition excluding OMIBs in our data set. Second, the USA is also exceptional in the sense that the self-employment data from OECD National Accounts are exclusive of unpaid family workers, see OECD (1997a: 73). Since in the USA the number of unpaid family workers is very low $(0.1 \%$ of total nonagricultural employment in 1996; compare this with, for example $4.1 \%$ in Turkey, see OECD, 1997b), this discrepancy in definition with regard to the other countries is very small.

11. This publication also provides data for years prior to 1983 , by means of accompanying disks.

12. We are grateful to Jose Mata for providing us with the last-mentioned data.

13. We use the LSQ command in TSP 4.5.

14. The removal of uneven years has the advantage of diminishing the potential danger of a downward bias in the estimated standard errors of the coefficients that may arise due to overlapping observation periods for consecutive years. The key variables like business ownership rate and GDP per capita change only slowly over time. Hence, it is unlikely that the results will alter much in case the uneven years would have been included.

15. In Van Stel and Carree (2002) we provide additional empirical evidence for the validity of the equilibrium curve depicted in Figure 1. In particular, we show that allowing for country-specific (hence lower) equilibrium functions is unattractive, both statistically and theoretically. We find no growth penalty any more because structural differences between countries are removed and only time-specific deviations are left.

16. Note that the large distance from equilibrium for Italy (Figure 2) is consistent with the high value of the Italy-dummy in Table 3, while the small distance from equilibrium for manufacturing (Figure 1) is consistent with the low value of the Italy-dummy in Table 2.

17. Because equation (4) is estimated separately (i.e. not in an error-correction type of equation like [1]), the estimated function should not be interpreted as an equilibrium, but rather as an average.

18. Empirical evidence of the impact of sectoral composition on economic growth can be found in Fagerberg (2000) and Carree (2003). They find evidence that countries that have a relatively large or growing share of the electronics industry show relatively high subsequent productivity growth in manufacturing.

19. This is not caused by multi-collinearity as mutual correlations between the three variables are low.

\section{References}

Acs, Z. J. (1996) 'Small Firms and Economic Growth', in P. H. Admiraal (ed.) Small Business in the Modern Economy, pp. 1-62. Oxford: Blackwell.

Acs, Z. J., Audretsch, D. B. and Evans, D. S. (1994) 'The Determinants of Variation in the Self-employment Rates across Countries and over Time', mimeo (fourth draft).

Audretsch, D. B., Carree, M. A., Van Stel, A. J. and Thurik, A. R. (2002) 'Impeded Industrial Restructuring: The Growth Penalty', Kyklos 55(1): 81-98. 
Van Stel and Carree: Business Ownership and Sectoral Growth

Audretsch, D. B. and Thurik, A. R. (2000) 'Capitalism and Democracy in the 21st Century: From the Managed to the Entrepreneurial Econony', Journal of Evolutionary Economics $10(1): 17-34$.

Bleaney, M. and Nishiyama, A. (2002) 'Explaining Growth: A Contest Between Models', Journal of Economic Growth 7(1): 43-56.

Carree, M. A. (2002a) 'Industrial Restructuring and Economic Growth', Small Business Economics 18(4): 243--55.

Carree, M. A. (2002b) 'Does Unemployment Affect the Number of Establishments? A Regional Analysis for US States', Regional Studies 36(4): 389-98.

Carree, M. A. (2003) 'Technological Progress, Structural Change and Productivity Growth: A Comment', Structural Change and Economic Dynamics 14(1): 109-15.

Carree, M. A., Van Stel, A. J., Thurik, A. R. and Wennekers, A. R. M. (2000) 'Business Ownership and Economic Growth in 23 OECD Countries'. Tinbergen Institute Discussion Paper TI 20001-01/3, Tinbergen Institute, Rotterdam.

Carree, M. A., Van Stel, A. J., Thurik, A. R. and Wennekers, A. R. M. (20012) 'Economic Development and Business Ownership', Small Business Economics 19: 271-90.

Carree, M. A. and Thurik, A. R. (1998) 'Small Firms and Economic Growth in Europe'. Atlantic Economic Journal 26: 137-46.

Chandler, A. D., Jr (1990) Scale and Scope: The Dynamics of Industrial Capitalism. Cambridge, MA: Harvard University.

Ellman, M. (1993) 'General Aspects of Transition', in P. H. Admiraal (ed.) Economic Transition in Eastern Europe. Oxford: Blackwell.

Evans, D. S. and Leighton, L. S. (1989) 'Some Empirical Aspects of Entrepreneurship', American Economic Review 79(3): 519-35.

Fagerberg, J. (2000) 'Technological Progress, Structural Change and Productivity Growth: A Comparative Study', Structural Change and Economic Dynamics 11(4): 393-411.

Jackson, L. F. (1984) 'Hierarchic Demand and the Engle Curve for Variety', Review of Economics and Statistics 66(1); 8-15.

Jensen, M. C. (1993) 'The Modern Industrial Revolution, Exit, and the Failure of Internal Control Systems', Journal of Finance 48(3): 831-80.

Klepper, S. (1996) 'Entry, Exit, Growth, and Innovation over the Product Life Cycle', American Economic Review 86: 562-83.

Kuznets, S. (1971) Economic Growth of Nations, Total Output and Production Structure. Cambridge, MA: Harvard University Press and Belknapp Press.

Maslow, A. H. (1970) Motivation and Personality. New York: Harper and Row.

Meredith, J. (1987) 'The Strategic Advantages of New Manufacturing Technologies for Small Firms', Strategic Management Journal 8: 249-58.

Nickell, S. J. (1996) 'Competition and Corporate Performance', Journal of Political Economy 104: 724-46.

OECD (1997a) National Accounts 1983-1995, Volume Il. Paris: OECD.

OECD (1997b) Labour Force Statistics 1976-1996. Paris: OECD.

OECD (2000) Employment Oullook June 2000. Paris: OECD.

Reynolds, P. D., Bygrave, W. D., Autio, E., Cox, L. W. and Hay, M. (2002) Global Entrepreneurship Monitor, 2002 Executive Report. Wellesley, MA: Babson College.

Reynolds, P., Storey, D. J. and Westhead, P. (1994) 'Cross-national Comparisons of the Variation in New Firm Formation Rates: An Editorial Overview', Regional Studies 28: $343-6$.

Schultz, T. P. (1990) 'Women's Changing Participation in the Labor Force: A World Perspective', Economic Development and Cultural Change 38: 457-88. 
International Small Business Journal 22(4)

Van Stel, A. J. (2003) 'COMPENDIA 2000.2: A Harmonized Data Set of Business Ownership Rates in 23 OECD Countries', EIM Research Report 200302. Zoetermeer, The Netherlands: EIM. URL (consulted May, 2003): http://www.eim.net

Van Stel, A. J. and Carree, M. A. (2002) 'Business Ownership and Sectoral Growth', EIM Research Report 200206. Zoetermeer, The Netherlands: EIM. URL (consulted December, 2002): http://www.eim.net

ANDRÉ VAN STEL, studied econometrics at Erasmus University Rotterdam. He is currently employed as a researcher by EIM Business and Policy Research in Zoetermeer, The Netherlands. Furthermore, André is preparing a PhD thesis on the relationship between entrepreneurship and economic growth. He plans to defend his PhD thesis at Erasmus University Rotterdam in Autumn 2004. His supervisors are Roy Thurik and Martin Carree.

Please address correspondence to: André van Stel,

EIM Business and Policy Research, P.O. Box 7001, 2701 AA Zoetermeer,

The Netherlands. [email: ast@eim.nl]

MARTIN CARREE. is Professor of industrial organization at the Faculty of Economics and Business Administration of Universiteit Maastricht. He received his PhD degree from Erasmus University Rotterdam in November 1997. Martin has published in a range of journals including Economic Systems, Economics Letters, International Journal of Industrial Organization, Journal of Marketing Research, Regional Studies, Review of Economics and Statistics, Small Business Economics and Southern Economic Journal.

Please address correspondence to: Martin Carree,

University of Maastricht, P.O. Box 616, 6200 MD Maastricht,

the Netherlands. [email:m.carree@os.unimass.nl] 
Van Stel and Carree: Business Ownership and Sectoral Growth

\section{Appendix: Data Availability}

The various estimations in the present article were performed using data from the database 'BLISS Oeso Sectoraal'. As this is an unbalanced panel, different numbers of observations per country are used for different est imations. The exact data per country used in the various estimations are reported in this appendix.

In Table Al the construction of the estimation samples used for the various estimations in this report is given. For manufacturing, there are 245 observations in total, and for services 231 (see Tables 2, 3 and 5). The maximum number of observations for a country is 13 (1974-98; only even years). (The actual number of available years is 15 (1970-98), due to the four-year lag in the model.) For countries having less than 13 observations the exact years available are reported in the table.

Table A1. Number of Observations per Country Used for Sector Estimations

\begin{tabular}{lll}
\hline Country & Manufacturing & Services \\
\hline Austria & $10(1980-98)$ & $10(1980-98)$ \\
Belgium & 13 & $10(1980-98)$ \\
Denmark & 13 & 13 \\
Finland & 13 & 13 \\
France & 13 & 13 \\
West Germany & 13 & 13 \\
Greece & $12(1976-98)$ & $12(1976-98)$ \\
Ireland & $8(1980-94)$ & - \\
Italy & 13 & 13 \\
The Netherlands & 13 & 13 \\
Portugal & $11(1978-98)$ & 13 \\
Spain & $12(1976-98)$ & $5(1990-98)$ \\
Sweden & 13 & 13 \\
United Kingdom & $12(1976-98)$ & $12(1976-98)$ \\
Iceland & $8(1984-98)$ & $8(1984-98)$ \\
Norway & 13 & 13 \\
United States & $12(1974-96)$ & $12(1974-96)$ \\
Japan & 13 & 13 \\
Canada & $10(1980-98)$ & $10(1980-98)$ \\
Australia & $11(1978-98)$ & 13 \\
New Zealand & $9(1982-98)$ & $9(1982-98)$ \\
TOTAL & 245 & 231 \\
\hline
\end{tabular}

Note: Maximum number of observations is 13 (1974-98).

As we saw in Table 5, the number of observations used for the macro estimations is 227 . This number is obtained by taking the intersection of the manufacturing and services samples. In Table A1, compared to the services sample of 231 observations, only for Portugal and Australia there are missing observations for manufacturing (viz. 1974 and 1976, for both countries). 
International Small Business Journal 22(4)

Business ownership et croissance sectorielle

Une analyse empirique de 21 pays membres de l'OCDE - André van Stel

EIM Business \& Policy Research, Pays-Bas

Martin Carree

Université de Maastricht, Pays-Bas

Nous procédons à un recensement des Business ownerships (travail indépendant), sur une échelle de temps donnée, au niveau sectoriel, et à une recherche sur l'impact que peuvent avoir ces statistiques sur la croissance de la production sectorielle. Lors d'un exercice précédent, Carree et al. avaient présenté une analyse de l'interdépendance existant entre les pourcentages des Business ownerships au niveau économique général et le développement économique proprement dit. Cette analyse a soulevé une question de recherche importante, à savoir jusqu'à quel point les différences de pourcentages des Business ownerships au niveau économique général révèlent les différences existant dans les structures sectorielles des économies, ou les différences relevées dans les pourcentages des Business ownerships au niveau sectoriel? Le présent exposé étudie cette question, s'appuyant sur une base de données sectorielle établie par 21 pays membres de l'OCDE entre 1970 et 1998. Les résultats des estimations suggèrent que le pourcentage de Business ownerships de fabrication est en moyenne trop faible par rapport au taux trop élevé des Business ownerships de services professionnels.

Mots clés: business ownership; croissance économique; entrepreneuriat; fabrication; services

Los propictarios empresarios y el crecimiento sectorial

Un análisis empírico de 21 países miembros de la OCDE - André van Stel

EIM Business and Policy Research, Países Bajos

Martin Carree

Universidad de Maastricht, Paises Bajos

Este artículo investiga el desarrollo de las tasas de propietarios empresarios (autoempleo) en función del tiempo a nivel sectorial y el efecto que tienen dichas tasas en el aumento de la producción sectorial. En un trabajo anterior, Carrée et al. presentaron un análisis de la interrelación entre las tasas de propietarios empresarios a escala de economía y el desarrollo económico. Su análisis plantea una importante cuestión de investigación: ¿hasta qué punto las tasas de propietarios empresarios a escala de economía reflejan las diferencias en las estructuras sectoriales de las economías o las diferencias en las tasas de propietarios empresarios a nivel sectorial? El presente artículo examina esta cuestión utilizando una base de datos sectoriales de 21 países miembros de la 0CDE (Organización de Cooperación y Desarrollo Económicos) para el periodo entre 1970 y 1998. Los resultados previstos sugieren que, como término medio, hay una tasa demasiado baja de propietarios empresarios en el sector industrial y una tasa demasiado alta de propietarios empresarios en el sector de servicios.

Palabras claves: propietarios empresarios; crecimiento económico; iniciativa empresarial; sector industrial; sector de servicios 
Van Stel and Carree: Business Ownership and Sectoral Growth

Geschäftsbesitz und Sektorenwachstum

Eine empirische Analyse von 21 OECD-Ländern - André van Stel

EIM Business and Policy Research, Niederlande

Martin Carree

Universität von Maastricht, Niederlande

Wir untersuchen die Entwicklung der Geschäftsbesitzraten (selbständige Tätigkeit) auf Sektorebene im Laufe der Zeit sowie die Auswirkung dieser Raten auf das Sektorproduktionswachstum. In einer früheren Studie präsentierten Carree et. al. eine Analyse der Wechselbeziehung zwischen wirtschaftsweiten Geschäftsbesitzraten und wirtschaftlicher Entwicklung. Deren Analyse warf eine wichtige Forschungsfrage auf: Inwieweit spiegeln die Unterschiede in Geschäftsbesitzraten auf wirtschaftsweiter Ebene die Unterschiede in den Sektorstrukturen von Volkswirtschaften wieder bzw. inwieweit reflektieren sie die Unterschiede von Geschäftsbesitzraten auf Sektorebene? Der vorliegende Beitrag untersucht diese Frage, indem eine Sektordatenbank von 21 OECD-Ländern für den Zeitraum von 1970 bis 1998 ausgewertet wird. Schätzungsergebnisse weisen darauf hin, dass im Durchschnitt eine zu niedrige Geschäftsbesitzrate in der Fertigung und eine zu hohe Geschäftsbesitzrate im Dienstleistungssektor vorliegt.

Schlagwörter: Geschäftsbesitz; wirtschafiliches Wachstum; Unternehmerschaft; Fertigung; Dienstleistungen 